\author{
From the \\ Veterinary Faculty of the \\ Ludwig-Maximilian-University Munich \\ Institute of Molecular Animal Breeding and Biotechnology \\ Univ.-Prof. Dr. E. Wolf
}

\title{
Evaluation of Laser-Assisted Lentiviral Transgenesis in Bovine
}

\author{
Inaugural Dissertation \\ to achieve the Doctor Title of Veterinary Medicine \\ from the Faculty of Veterinary Medicine \\ of the Ludwig-Maximilian-University Munich
}

by Sonja Ewerling

from

Pfaffenhofen / IIm

Munich, April 2006 
Gedruckt mit der Genehmigung der Tieraerztlichen Fakultaet der Ludwig-Maximilians-Universitaet Muenchen

Dekan: Univ.-Prof. Dr. E. P. Maertlbauer

Referent: $\quad$ Univ.-Prof. Dr. E. Wolf

Koreferent: $\quad$ Prof. Dr. M. El-Matbouli

Tag der Promotion: 28. Juli 2006 


\section{Abbreviations}

AC

Al

BAC

BSSL

BSE

r28M

CAG

CMV

COC

CpG

DNA

eGFP

EPO

ES

$\mathrm{FSH}$

GFP

GV

HAC

HIV

IGHM

IVC

IVF

IVM

IVP

$\mathrm{kb}$

LH

LOS

LR geo L

(VSV-G)

LTR artificial chromosome

artificial insemination

bacterial artificial chromosome

bile salt stimulated lipase

bovine spongiform encephalopathy

bispecific antibody

chicken beta actin

cytomegalovirus

cumulus-oocyte complex

cytidin-guanosin

deoxyribonucleic acid

enhanced green fluorescent protein

Erythropoetin

embryonic stem

follicle stimulating hormone

green fluorescent protein

germinal vesicle

human artificial chromosome

human immunodeficiency virus

Immunoglobulin $\mu$

in vitro culture

in vitro fertilization

in vitro maturation

in vitro production

Kilobase

luteinizing hormone

large offspring syndrome

neomycin phosphotransferase and $\beta$-galactorsidase fusion gene expressed from Rous Sarcoma Virus

(vesicular stomatitis virus glycoprotein pseudotyped)

long terminal repeat 
Microinjection

M-MuLV

murine Moloney leukemia virus

NT

nuclear transfer

OPU

ovum pickup

PRNP

prion protein

PBS

phosphate buffered saline

pl

pico liter

pgk

phosphoglycerate kinase

RNA

ribonucleic acid

n. r.

not reported

SEM

standard error

SIN

self inactivating

SOF

synthetical oviduct fluid

TALP

Tyrode albumin lactate pyruvate

TFF

transfected fetal fibroblast

TRFF

transgenic fetal fibroblast

VSV G

vesicular stomatitis virus glycoprotein

wt

wild-type

YAC

yeast artificial chromosome

ZP

Zona pellucida 


\section{Table of contents}

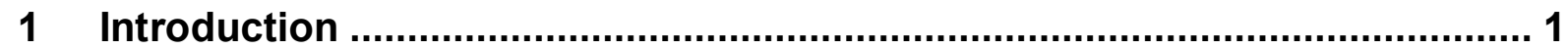

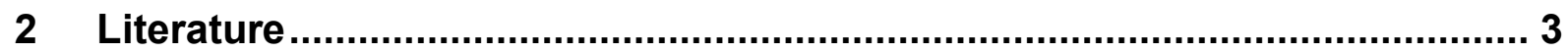

2.1 Transgenesis in bovine and other livestock species................................. 3

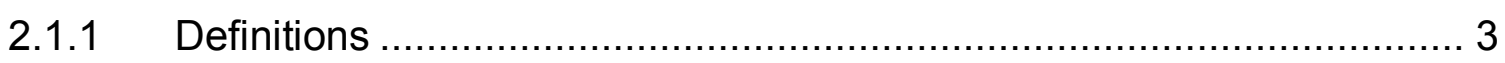

2.1.1.1 Pronuclear microinjection (MI) ............................................. 4

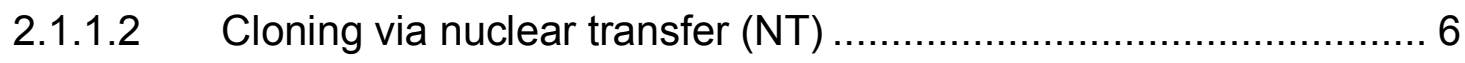

2.1.2 Application fields for transgenic livestock...................................... 10

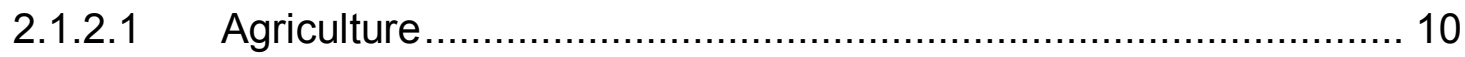

2.1.2.2 Biopharmaceuticals (gene pharming)..................................... 10

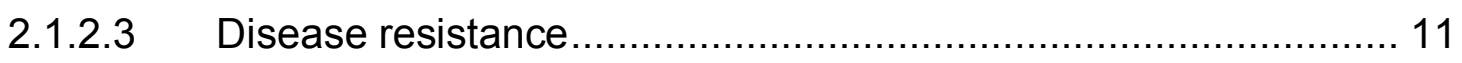

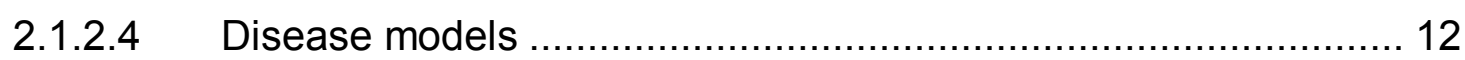

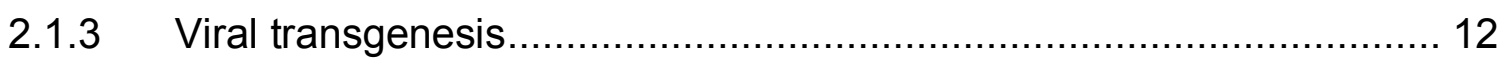

2.1.3.1 Viral transgenesis in bovine ............................................... 12

2.1.3.2 Vector design ................................................................ 13

2.1.3.3 RNA virus vectors .......................................................... 15

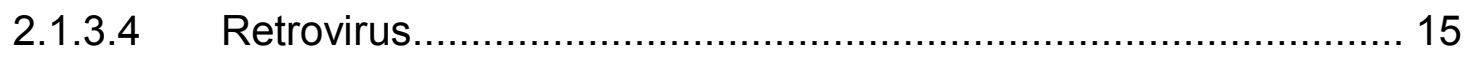

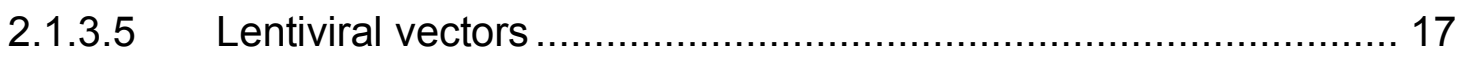

2.2 In vitro production (IVP) of bovine embryos …..................................... 20

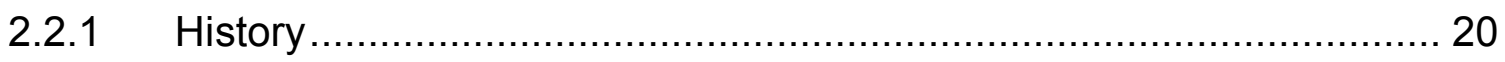

2.2.2 Recovery of ovaries and oocyte collection ..................................... 20

2.2.3 Assessing oocyte quality ................................................................. 21

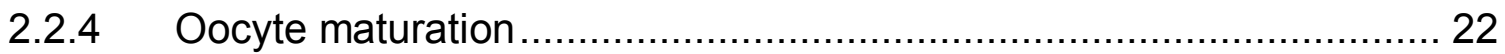

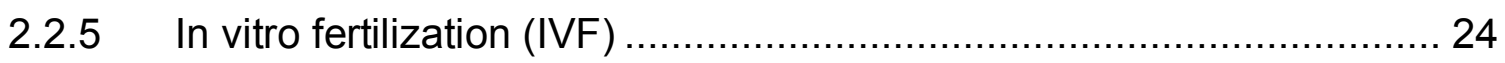

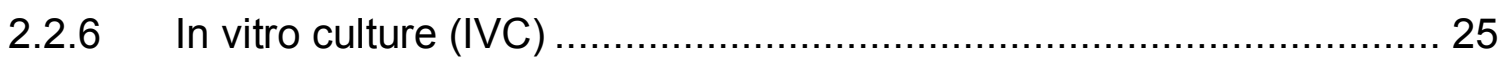

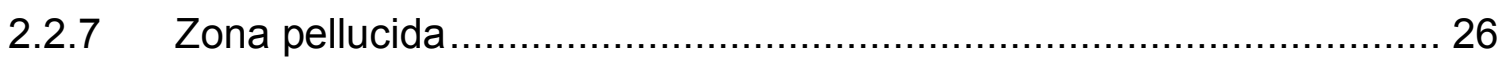

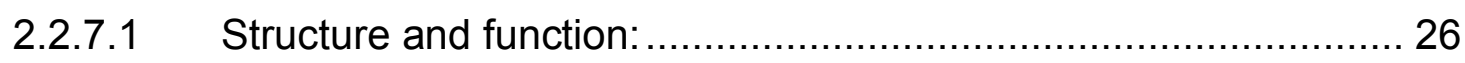

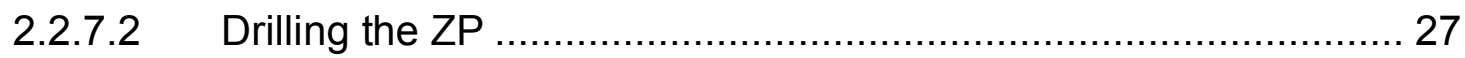

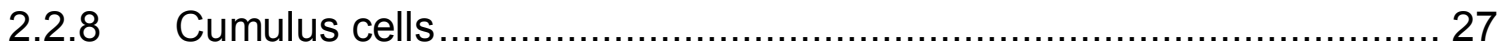

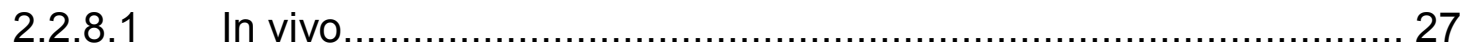

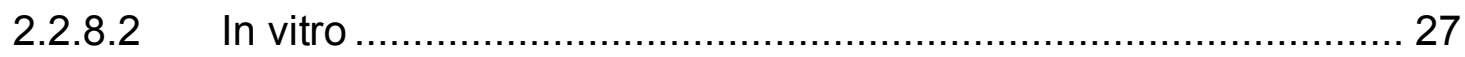

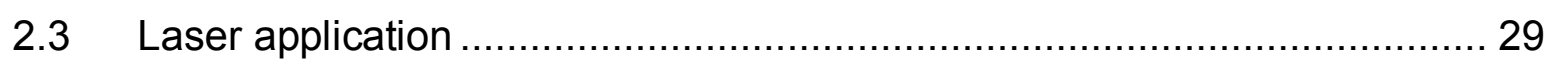

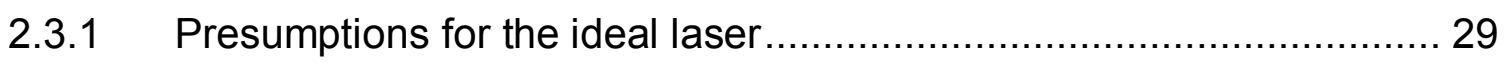

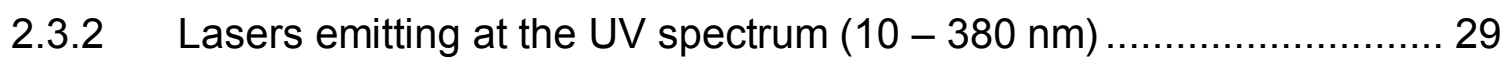


2.3.3 Lasers emitting at the infrared spectrum $(780 \mathrm{~nm}-50 \mu \mathrm{m}) \ldots \ldots \ldots \ldots . . .30$

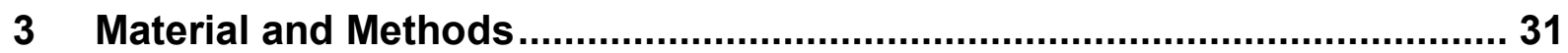

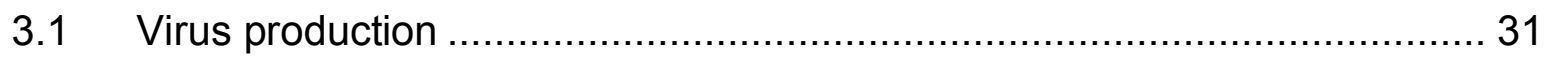

3.2 In vitro production of bovine embryos......................................... 31

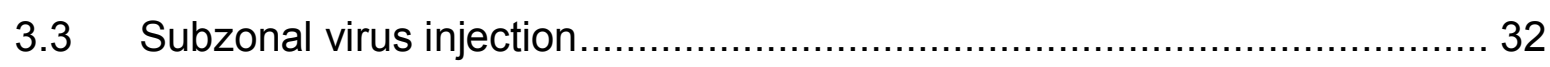

3.4 Microdrilling and virus coincubation............................................ 33

Effect of treatment and developmental stage .................................. 36

3.6 Determination of polyspermy rate ...................................................... 37

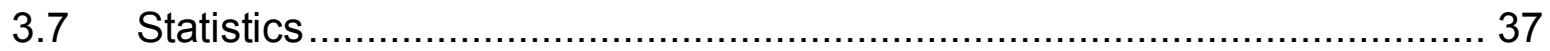

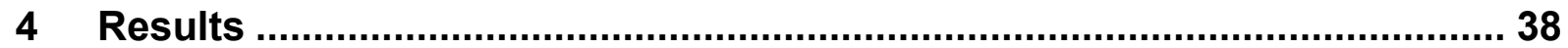

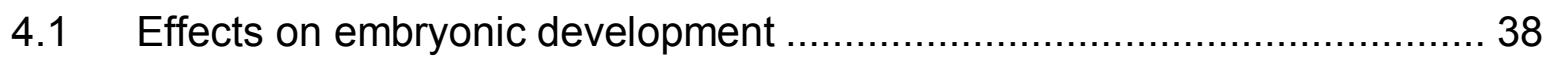

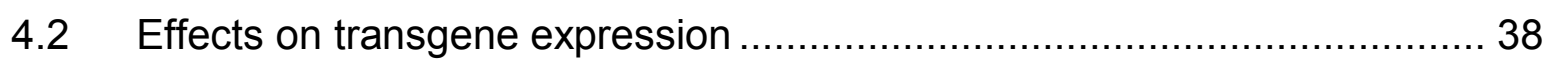

4.3 Effect of microdrilling of oocytes on polyspermy.............................. 40

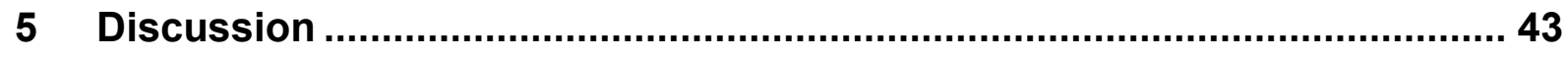

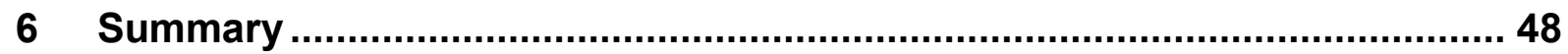

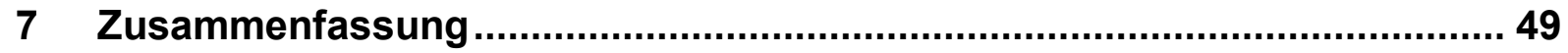

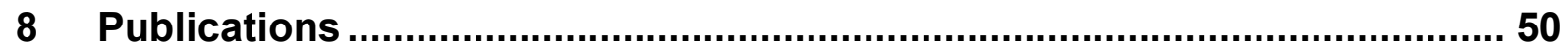

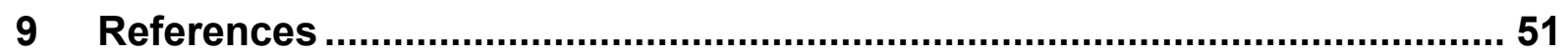

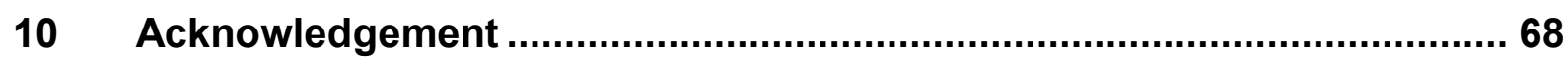




\section{Introduction}

Transgenic animal research has a history of more than 25 years. Transgenic mammals were created with the aim to answer questions ranging from basic research, such as the role of differently expressed genes in pathologically altered organisms compared to healthy animals, which is done mostly in rodents, up to commercial aspects of animal breeding, such as changing milk (Wall et al., 1997) or body composition (Pursel et al., 1989), or the metabolism of farm animals (Golovan et al., 2001).

Most transgenic research is done on rodents, but the ability to modify the genome of farm animals in a similar manner would be a great benefit to agriculture as well as veterinary and human medicine (Piedrahita et al., 1999).

In mice several strategies for gene transfer into embryos have been developed, such as the production of chimeric mice by injection of pluripotent embryonic stem (ES) cells into mouse blastocyts as gene-driven approach (Evans and Kaufman, 1981). ES cells can be genetically modified via transfection with DNA (Gossler et al., 1986) or via homologous recombination to obtain knock-out mice or mice with homologous recombinated gene loci (Brem, 1993).

In farm animals germline competent embryonic stem cells are not available, despite considerable efforts to isolate them (Denning and Priddle, 2003). Therefore transgenic livestock had to be produced by microinjection into the pronuclei of zygotes (Hammer et al., 1985; Brem et al., 1985), where gene integration occurs randomly and gene expression can not be guaranteed. Pronuclear microinjection works rather well in mice, where about 10 animals are required per transgenic founder, but efficiency in livestock is much lower. 20 pigs and 80 cattle are necessary for one transgenic founder in these species (Brem, 1993). Improvement of in vitro embryo production techniques of livestock species, particularly in cattle, reduced the costs of creating transgenic livestock via microinjection dramatically and allowed the development of nuclear transfer of cells into in vitro matured oocytes. Combined with targeted transgenesis via homologous recombination in somatic donor cells the creation of transgenic and expressing livestock became possible (Schnieke et al., 1997). But also NT was shown to suffer from low efficiencies and the resulting 
offspring often exhibitvarious developmental abnormalities, which are commonly summarized as "large offspring syndrome (LOS)" (Heyman, 2005).

Therefore new routes of gene transfer in livestock species are still of high interest for biomedical research. Recent publications have shown that lentiviral vectors are highly efficient for the generation of transgenic mammals (for review see (Pfeifer, 2004)), such as mouse (Lois et al., 2002a; Pfeifer et al., 2002), rat (Nakagawa et al., 2005), pig (Hofmann, et al. 2003 ), cattle (Hofmann et al., 2003; Hofmann et al., 2004) and chicken (McGrew et al., 2004). In our previous studies, we used HIV-1 based lentiviral vectors which contain a self-inactivating (SIN) mutation for the generation of transgenic pigs and cattle (Hofmann et al., 2003a; Hofmann et al., 2004). Oocytes and preimplantation embryos are protected by their zona pellucida (ZP), which is a physical barrier for viral infection. So far two different methods have been applied to overcome this hurdle for lentiviral transduction: a) denudation of the embryos by acid tyrode treatment and incubation in virus suspension (Pfeifer et al., 2002) and b) subzonal injection of virus particles into the perivitelline space (Lois et al., 2002). A potential alternative to these state-of-the-art methods in lentiviral transgenesis is laser-based zona microdrilling and subsequent culture of embryos in virus suspension. Laser-assisted penetration of the ZP is routinely established, e.g. in human assisted reproduction techniques (ART) such as intracytoplasmic sperm injection (ICSI) or assisted hatching (Seif et al., 2005). The laser technology allows for precise and reproducible creation of a hole of desired size in the ZP without damaging the underlying cytoplasm (Rink et al., 1996a). This procedure is easy to perform and does not require special skills of the operator.

The present study evaluates the efficacy of laser-assisted lentiviral gene transfer in bovine as compared to the subzonal injection technique. Both methods were used for oocytes and zygotes, in order to optimize lentiviral gene transfer with regard to the proportions of embryos surviving and expressing the transgene. 


\section{Literature}

\subsection{Transgenesis in bovine and other livestock species}

Until today the number of transgenic cattle remains low. High costs and low efficiency of the available methods to create well expressing transgenic livestock could not be overcome sufficiently, although the importance and high value of such animals is emphasized enthusiastically by many authors (Wall et al., 1985; Eyestone et al., 1998; Piedrahita et al., 1999; Wall et al., 1992; Wall et al., 1997; Clark, 1998; Brem and Brening, 1985; Chan, 1999; Clark and Whitelaw, 2003; Colman, 1996; Denning and Priddle, 2003; Donovan et al., 2005; Eyestone, 1994; Golovan et al., 2001; Grosse-Hovest et al., 2004; Hammer et al., 1985; Haskins et al., 2002; Hofmann et al., 2003; Hofmann et al., 2004; Hyttinen et al., 1994; Melo et al., 2005; Muller and Brem, 1998; Petters, 1994; Schnieke et al., 1997; Seamark, 1994; Wolf et al., 2000) The success of pronuclear microinjection or cloning is evident in the generation of transgenic cattle but its limitations have hindered progress of bovine transgenics (Hodges and Stice, 2003; Maga, 2005).

\subsubsection{Definitions}

Gene transfer is the incorporation of new DNA into organism's cells (http://www.ornl.gov/sci/techresources/Human_Genome/glossary/glossary_g.shtml). The term "transgene" was first used for animals, which had integrated in vitro recombinated gene constructs into their genome (Gordon and Ruddle, 1981). Bacterial, yeast, and higher eukaryotic cells harboring a foreign DNA fragment are known as recombinant or transformed cells (Houdebine, 2003). Gene constructs may stay episomal or integrate into the genome of somatic and/or germ line cells at one or more sites. Depending on the method used, integration occurs by chance (MI), or randomly into genes, which were found to be strongly favored as integration acceptor sites for HIV-1 derived vectors (Schroder et al., 2002). One major problem of transgenesis is mosaicism, which means that not all cell lines of the organism contain the transgene. Transgenic animals are hemizygote for the transgene, not heterozygote, because heterozygocity requires a homologous allele. Integration requires breaking of the DNA and its subsequent repair, thus causing the risk of 
insertional mutagenesis. The two methods most commonly used to create transgenic cattle are microinjection of DNA into the pronuclei of zygotes and cloning via nuclear transfer.

\subsubsection{Pronuclear microinjection (MI)}

Injection of DNA into pronuclei of zygotes has been consistently used in mice since 1981 (Gordon and Ruddle, 1981) and in farm animals since 1985, when Hammer et al. (1985) and Brem et al. (1985) demonstrated the feasibility of this procedure. About 500 - 5000 copies of foreign DNA are injected into a pronucleus, which are diluted in $1-2$ pl buffer solution. Zygotes from large animals can be obtained either after superovulation ex vivo, or after in IVM and IVF of oocytes, collected from slaughterhouse ovaries or via ovum pick up (OPU) from live donor animals. Due to their high lipid content, zygotes of ruminants and pigs have a dark cytoplasm, which makes the pronuclei invisible. Centrifugation prior Ml assembles the lipid granules at one side of the embryo and makes the pronuclei visible. This treatment did not seem to have any negative influence on the developmental capacity of the zygotes (Wall et al., 1985; Wall and Hawk, 1988). The efficiency of $\mathrm{Ml}$ in farm animals is low (< 1\%) (Chan, 1999) (Table 1). On average, 40 embryos of mice, 100 pig embryos, 110 sheep embryos and 1600 bovine embryos are required for a single transgenic offspring (Wall et al., 1997). The behaviour of a transgene is unpredictable; the site of integration can not be controlled and expression may vary due to position effects (Wolf et al., 2000). Furthermore, endogenous genes can be destroyed by the integration of the foreign DNA (insertional mutagenesis). This could be a reason of reduced developmental capacity of pronuclear injected zygotes (Eyestone et al., 1995). The recommended time point for microinjection in bovine is at the end of the S-phase of the cell cycle, where DNA synthesis occurs (Krimpenfort et al., 1991).

For construct composition the following features are recommended (http://www.biotech.wisc.edu/ServicesResearch/TransgenicAnimal/TransgenicMiceor Rats.asp):

1) a promoter with a known cellular expression profile

2) a genomic clone or cDNA and intron fragment containing splice donor and receptor sites

3) a fragment containing polyadenylation addition sequences, to ensure mRNA stability 
4) well characterized restriction sites that will allow the isolation of an injection transgenic fragment free of prokaryotic vector sequences

The size of the DNA determines the molar concentration and therefore the number of copies of the gene per injection sample. An ideal fragment size is between $2 \mathrm{~kb}$ and $20 \mathrm{~kb}$. To have a fragment much under $2 \mathrm{~kb}$ is not recommended because, empirically, it usually does not integrate very efficiently. The larger the DNA or the more different fragments that are in the injection sample, the lower the final copy number of individual genes becomes in that sample (http://cancer.ucsd.edu/Research/Shared/tgm/pronuclear.asp).

Attempts to counteract the position effects and to cause a targeted overexpression of the transgene lead to the development of complex vector systems, such as minigenes (Loveland et al., 2004) or artificial chromosomes (AC), being produced with the help of organisms such as Yeast (YAC) or bacteria (BAC). This technique allows addition of DNA fragments up to $250 \mathrm{~kb}$ into a host's genome, as Brem et al.(1996) showed by introducing a YAC-DNA clone into rabbits. 


\subsubsection{Cloning via nuclear transfer (NT)}

Cloning is the reproduction of a cell or a whole organism without any modification of its genotype (Houdebine, 2003). The ability to duplicate an organism requires totipotency, which is defined as a cell characteristic in which the potential for forming all the cell types in the adult organism is retained (www.sivb.org/edu terminology.asp). In farm animals true cloning can be achieved by embryo splitting, where genetically identical twins can be produced by splitting a two cell embryo (Gordon, 2003) up to the blastocyst stage (Lewis, 1994). Monocygotic twins are identical with respect to both nuclear and mitochondrial DNA (Wolf et al., 2003).

To increase the number of genetically almost identical offspring NT has been developed. Oocytes contain mitochondrial DNA, which contributes to the genetic setting of an individual as well as the donor nucleus and can therefore, depending on the oocyte origin, vary (Han et al., 2004; Hiendleder et al., 2003). Three main steps are required for NT: 1) Removal of maternal chromatin from a recipient oocyte; 2) introduction of a donor nucleus into the recipient oocyte; and 3) activation of the reconstructed oocyte (Gordon, 2003). The donor cells can be blastomeres from cleavage-stage embryos (Zakhartchenko et al., 1995), fetal cells (Hill et al., 2000) or adult somatic cells (Wilmut et al., 1997) (Table 1). For successful development of embryos resulting from NT, the donor nuclei have to obtain an embryonic pattern of DNA replication and transcription under the control of the recipient oocytes. It is recommended that the donor cells should be in the M phase or $\mathrm{G} 1$ phase of the cell cycle when used for NT (Renard et al., 2002). All cells of a multicellular organism, except for lymphocytes, contain the same genetic information, but differ in tissuespecific, temporal, and spatial gene expression patterns which are controlled by genetic and epigenetic mechanisms. Successful cloning of mammals by transfer of nuclei from differentiated tissues into enucleated oocytes demonstrates that epigenetic reprogramming can restore cellular totipotency (Shi et al., 2003). Incomplete or inappropriate epigenetic reprogramming of donor nuclei is likely to be the primary cause of failures in NT (Shi et al., 2003).

The use of genetically modified cells as donor cells for NT has shown to be appropriate for targeted transgenesis in farm animals and ensures that all offspring is transgene. Via IVC of somatic cells over several passages, it is possible to transfect 
stably the cells with a construct containing the gene in question, together with a promoter with tissue specific or ubiquitous expression. This transfection requires homologous recombination, which is defined as a process whereby a specific gene sequence within the genome is replaced with a related gene sequence using the cellular recombination enzymes (http://www.cardiogenesis.com/glossary.cfm). This process results in the modification of a specific gene. Homologous recombination is a rare event, which only happens at a frequency of $1 \times 10^{-6}$ targeted events per cells manipulated (Piedrahita et al., 1999), which is 100 times less frequent than random integration (Houdebine, 2003). Transfected cells are selected with a selection marker and can be used as donor cells accordingly (Gordon, 2003). Current studies report an improvement in isolating transfected mammalian cells and in diagnosing the incorporation of desirable vectors in NT embryos (Melo et al., 2005; Maga, 2005). 
Table 1 Transgenic cattle

\begin{tabular}{|c|c|c|c|c|}
\hline Construct & Method & $\begin{array}{c}\text { Live transgenic calves } / \\
\text { injected or reconstructed } \\
\text { embryo }\end{array}$ & $\begin{array}{l}\text { Expression } \\
\text { of the } \\
\text { transgene }\end{array}$ & Reference \\
\hline casein hIF & $\mathrm{MI}^{1}$ & $2 / 1154$ & n.r. & (Krimpenfort et al., 1991) \\
\hline IGF-1 gene & $\mathrm{MI}^{1}$ & $3 / 2259$ & n. r. & (Hill et al., 1992) \\
\hline $\begin{array}{l}\text { Human estrogen } \\
\text { receptor gene }\end{array}$ & $\mathrm{MI}^{1}$ & $1 / 4150$ & n. r. & (Hill et al., 1992) \\
\hline chicken c-ski gene & $\mathrm{Ml}^{1,2}$ & $2 / 2555$ & n. r. & (Bowen et al., 1993) \\
\hline EPO gene & $\mathrm{MI}^{1}$ & $1 / 859$ & n. r. & (Hyttinen et al., 1994) \\
\hline a-lactalbumin gene & $\mathrm{MI}^{1}$ & $7 / 25023$ & 1 우 & (Eyestone et al., 1998) \\
\hline b-galactosidase gene & NT & $3 / 276$ & n. r. & (Cibelli et al., 1998) \\
\hline $\begin{array}{l}\text { retroviral LR geoL } \\
\text { (VSV-G) vector }\end{array}$ & $\mathrm{MI}^{1}$ & $\begin{array}{l}4 / 836 \text { (oocytes infected) } \\
1 / 584 \text { (zygotes infected) }\end{array}$ & $\begin{array}{l}0 / 4 \\
0 / 1\end{array}$ & (Chan et al., 1998a) \\
\hline a-lactalbumin gene & $\mathrm{MI}^{1}$ & $18 / 36530$ & n.r. & (Eyestone, 1999) \\
\hline prochymosin gene & NT & $\begin{array}{c}3 \text { / } 213 \text { TFF cells } \\
2 \text { / } 511 \text { TRCF cells }\end{array}$ & n.r. & $\begin{array}{c}\text { (Zakhartchenko et al., } \\
\text { 2001) }\end{array}$ \\
\hline BSSL gene & NT & $8 / 363$ & $7 / 8$ & (Chen et al., 2002) \\
\hline $\begin{array}{l}\text { HAC with human } \\
\text { immuneglobulin loci }\end{array}$ & NT & $21 /$ n.r. & $21 / 21$ & (Robl et al., 2003) \\
\hline GFP & NT & $4 / 350$ & $4 / 4$ & (Bordignon et al., 2003) \\
\hline
\end{tabular}




\begin{tabular}{ccccc}
\hline $\begin{array}{c}\text { B- and K-casein } \\
\text { bi-scFV r28M }\end{array}$ & NT & $11 / 456$ & $11 / 11$ & (Brophy et al., 2003) \\
\hline GFP & NT & $9 / 309$ & $9 / 9$ & $\begin{array}{c}\text { (Grosse-Hovest et al., } \\
\text { 2004) }\end{array}$ \\
\hline $\begin{array}{c}\text { IGHM - / } \\
\text { IGHM - / - }\end{array}$ & NT & $13 / 153^{4}$ & $3 / 3$ & (Gong et al., 2004) \\
\hline $\begin{array}{c}\text { lentiviral GFP vector } \\
\text { gif }\end{array}$ & MI & $8 / 137^{4}$ & $8 / 8$ & (Kuroiwa et al., 2004) \\
\hline $\begin{array}{c}\text { modified lysostaphin } \\
\text { gene }\end{array}$ & NT & $4 / 48$ & $4 / 4$ & (Hofmann et al., 2004) \\
\hline
\end{tabular}

${ }^{1}$ in vitro

2 ex vivo

${ }^{3}$ live calves / implanted embryos

${ }^{4}$ live calves / embryos transferred 


\subsubsection{Application fields for transgenic livestock}

\subsubsection{Agriculture}

The first attempt of creating transgenic livestock was to overcome limitations of traditional breeding concerning selective genetic improvement for agricultural production traits, such as milk yield or body weight gain. Introduction of a growth hormone gene markedly increased growth rate and final size of mice (Palmiter et al., 1992), but did not work well in farm animals. Transgenic pigs carrying bovine growth hormone genes had only a slightly enhanced growth rate and reduced levels of fat, but these animals suffered from widespread deleterious effects, including susceptibility to stress, lameness and reduced fertility (Pursel et al., 1989). Changes in milk composition was another attempt to establish transgene technology. Proposed modifications included the increase of $\alpha$ - and $\beta$-casein with more phosphorylation sites, to improve thermal stability and increase the calcium content of the milk (Wall et al. 1997).

\subsubsection{Biopharmaceuticals (gene pharming)}

Although expectations concerning improvement of agricultural traits in livestock species were not fulfilled, new uses of transgenic farm animals continued to attract research funding (Clark, 1998). The aim was to investigate if transgenic animals were capable to synthesize large amounts of recombinant proteins with appropriate posttranslational modifications, which could not be provided by prokaryotic bacteria. Blood serum, milk, egg white, blood, urine, seminal plasma or silk worm cocoon were candidates to be the source of recombinant proteins at an industrial scale (Houdebine, 2000). Recently it could be shown that a bispecific single-chain antibody could be produced in the serum of transgenic rabbits and a herd of nine cloned, transgenic cattle. The bispecific protein, designated $\mathrm{r} 28 \mathrm{M}$, was directed to a melanoma-associated glycoprotein and the human CD28 molecule on T cells. Purified from the serum of transgenic animals, the protein was stable and fully active in mediating target cell-restricted $\mathrm{T}$ cell stimulation and tumor cell killing (GrosseHovest et al., 2004). 
Another source for recombinant protein is milk. The mammary gland is a highly efficient bioreactor and studies have shown that it can be the source of a variety of rather complex recombinant proteins (Colman, 1996; Clark, 1998). Examples were to add enzymes, such as human lactoferrin, to improve iron absorption, or to replace bovine milk protein genes with human equivalents to mimic human breast milk (Wall et al., 1997). Depending on the amounts of protein needed, transgenic rabbits (Coulibaly et al., 2002; Zinovieva et al., 1998), sheep (Duchler et al., 2002; Niemann et al., 1999) or cows (Thomassen et al., 2005) have been shown to be appropriate. But low expression levels of some recombinant proteins, serious side effects for the animal (when the protein enters the circulation), or insufficient post-translational modifications of the proteins are challenges which have to be overcome. Despite this, mammary gland-derived pharmaceuticals are in the final stages of product development (Donovan et al., 2005).

\subsubsection{Disease resistance}

Conventional breeding did - so far - not succeed to increase resistance to infections of the mammary gland. This provided a further application field for transgenic technology in farm animals. The proposed use of transgenic technologies to increase disease resistance in farm animals (Muller \& Brem 1998) was not reported to be successful until 2005: Mastitis in dairy cows is often caused by Staphylococcus aureus. This infection of the mammary gland causes considerable financial loss in dairy industry all over the world (Donovan et al., 2005). Since antibiotic treatment often was insufficient and breeding strategies failed, a transgenic approach was made. Via nuclear transfer, transgenic cattle were created which expressed lysostaphin, an antistaphylococcal enzyme, in the epithelial cells of the mammary gland (Wall et al., 2005). Although the lysostaphin concentrations in the milk of transgenic cows were lower than expected, it seemed to be a very promising approach to control staphylococcus infection of the mammary gland. Development of inducible expression constructs may improve public acceptance, because the milk would only contain foreign proteins when infection with Staphylococcus aureus has taken place (Rainard, 2005). 


\subsubsection{Disease models}

Rodent models as commonly used organisms for biomedical research provide invaluable data for understanding human diseases (Houdebine, 2003), but they have certain limitations due to their small size, short gestation time, different metabolism and limited life span. Transgenic large animal models provide a highly useful tool for biomedical research, particularly in regard to xenotransplantation, chronic diseases, genetic defects or questions concerning the species-specific biological mechanisms, such as embryo-maternal communication (Wolf et al., 2003). One example, where murine and primate metabolism are not compatible is cystic fibrosis. In humans this disease is caused by mutations of the CFTR gene. Mice whose CFTR gene has been knocked out do not develop the disease (Houdebine, 2003). Here transgenic large animal models may provide more useful data, since lungs of pigs and sheep show similarities to man in lung anatomy and their CFTR expression patterns in submucosal glands provide hope that they may develop lung disease similar to that seen in human CF patients (Hart, 2003). Human $\alpha-1$-antitrypsin (hAAT) is a plasma protein that inhibits elastase, a key enzyme in the inflammatory response that can lead to excessive tissue destruction as it is seen in CF patients (Denning and Priddle, 2003). Therefore hAAT is a candidate protein for treatment of CF lung disease. Transgenic sheep were produced which expressed hAAT in their milk (McCreath et al., 2000).

\subsubsection{Viral transgenesis}

Viruses are highly efficient vehicles for the transport of genetic information into a cell. They use the cellular machinery for the transport of genetic information into the nucleus, for integration into the host genome, for transcription and translation of viral genome into viral proteins and for packing and discharging manifold viral particles out of the cell. Use of viral vectors as gene delivery tools requires modifications of the viral genome to exclude any risk of wt infection and resulting damage for the cell.

\subsubsection{Viral transgenesis in bovine}

Retroviral infection was the earliest method used for gene transfer into embryos. Preimplantation mouse embryos (at the 4-8 cell stage) were infected with Moloney leukemia virus (M-MuLV) and the resulting animals developed a M-MuLV-induced 
leukemia. The infection of the embryos lead to integration of the virus into the germ line and the further generations showed the disease following mendelian rules (Jaenisch, 1976). The first report of transgenic cattle resulting from viral transgenesis was provided by Haskell et al. (1995). They placed retroviral packaging cells under the ZP of bovine embryos and produced several transgene mosaic fetuses, but no live animal. The first cattle via retroviral gene transfer was created by Chan et al. (Chan et al., 1998). They could obtain transgenic live calves from infected oocytes (4 /4) as well as from infected zygotes (1 / 4). No animal showed transgene expression, because the viral vector was silenced shortly after birth. Two major mechanisms have been identified for retrovirus silencing: trans-acting factors that bind to the viral promoters in the LTRs and methylation of the integrated retoviral genome and flanking host DNA sequences (Pfeifer et al., 2002).

Not until 2004 it could be shown that viral transgenesis lead to expressing animals. Bovine oocytes were infected with a modified retrovirus, a lentiviral vector, carrying a eGFP marker gene. They were cultured in vitro, and 8 resulting blastocysts, showing eGFP expression, were transferred to four recipients. Four calves from 3 pregnancies were born. All of them showed transgene expression (Hofmann et al., 2004).

\subsubsection{Vector design}

Viral vectors can be divided into two groups according to the basic virology of the parental viruses: non integrating and integrating (Pfeifer, 2004). The genome of non integrating viral vectors, such as adenoviruses, will get lost after several cell divisions, but these viruses have been shown to be useful in gene therapy approaches in cancer research (Gallo et al., 2005), or new developments of vaccines in veterinary medicine (Ferreira et al., 2005). For stable, long term expression in animals, only integrating viral vectors are suitable, since they are passed from cell to cell.

The first step of viral vector design is to identify the viral sequences responsible for replication and pathogenesis and those necessary for the production of infectious particles. Dispensable genes are deleted from the viral genome to reduce replication, pathogenicity and expression of immunogenic viral antigens. The transgene with transcriptional regulatory elements is inserted into the vector construct. A 
recombinant virus is generated by supplying the missing gene products required for replication and virion production in trans (Verma and Weitzman, 2005). (Fig. 1)

Fig 1 Lentiviral vector design (Pfeifer, 2004)

A: wild-type viral genome; rectangles: flanking LTRs, dark circle: pathogenic genes, will be deleted; light circles: packaging part of the viral genome

B: viral vector flanked by LTRs, containing necessary cis-acting sequences and the transgene (lengthwise rectangle);

C: viral proteins essential for production of infectious particles are expressed in trans by the packaging cell (D)

E: envelope protein (env) is provided that ensures infection of a broad spectrum of target cells, such as VSV-G

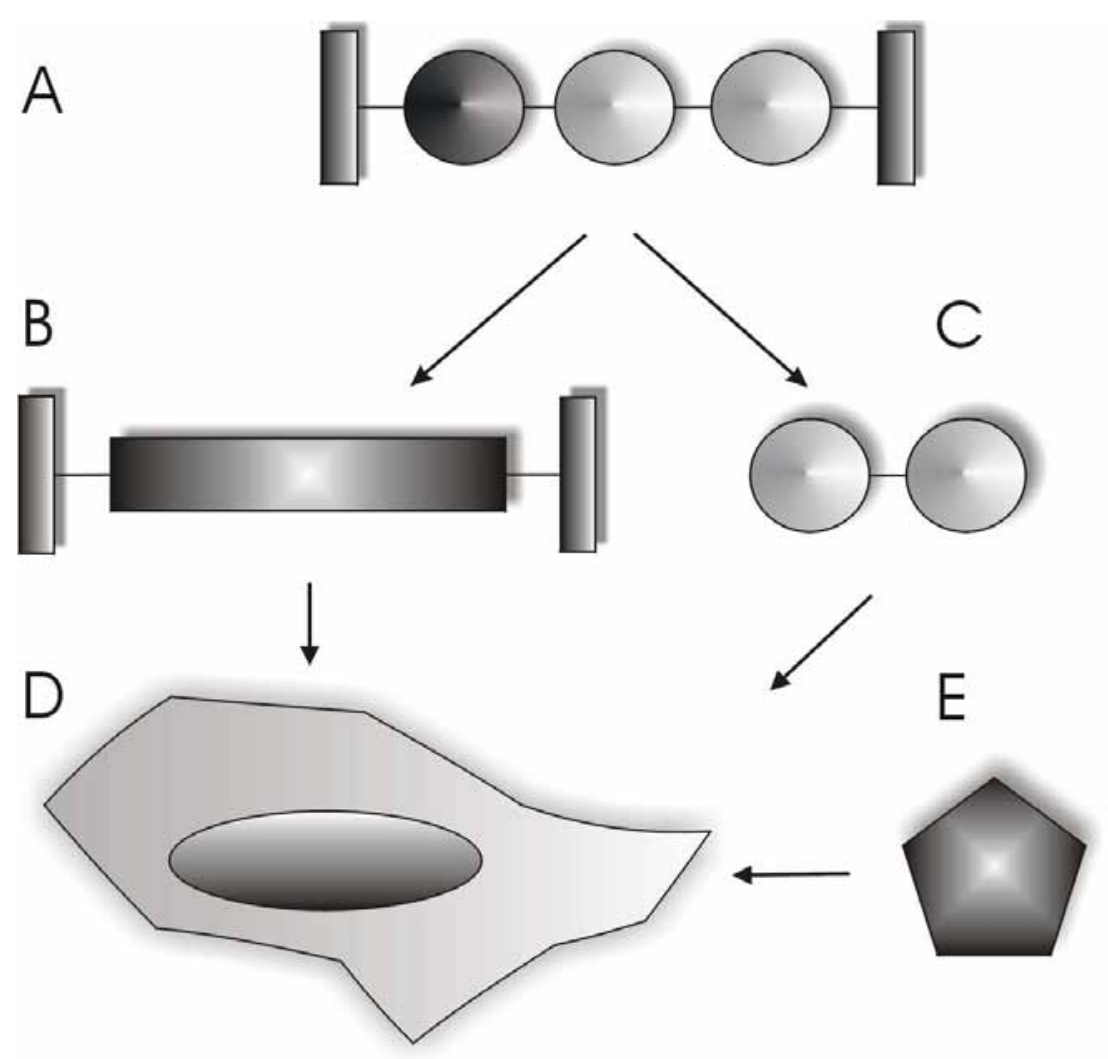




\subsubsection{RNA virus vectors}

The most commonly used RNA virus vectors are derived from retroviruses, a large family of enveloped RNA viruses found in all vertebrates. They can be classified into oncoretroviruses, lentiviruses and spumaviruses (Verma and Weitzman, 2005).

\subsubsection{Retrovirus}

Retroviruses are enveloped virus particles of approximately $100 \mathrm{~nm}$ in size, containing two copies of the viral RNA genome, which are surrounded by a cone shaped core (Fig. 2). The viral RNA contains three essential genes, gag, pol, and env and is flanked by long terminal repeats (LTR) (Verma and Weitzman, 2005). The gag gene encodes for the core proteins capsid, matrix, and nucleocapsid, which are generated by proteolytic cleavage of the gag precursor protein. The pol gene encodes for the viral enzymes protease, reverse transcriptase, and integrase, which are usually derived from the gag-pol precursor. The env gene encodes for the envelope glycoproteins, which mediate virus entry.

After binding to its receptor, the viral capsid enters the cell through membrane fusion. The viral enzyme reverse transcriptase converts viral RNA into a double-stranded proviral DNA, which is associated with viral proteins to mediate integration of the provirus into the host cell genome. Disruption of the nuclear membrane is required for the preintegration complex to gain access to the chromatin, and productive transduction by retroviral vectors is strictly dependent on target cell mitosis shortly after entry (Kay, Glorioso, et al. 2001). Host cell transcription factors initiate transcription starting at the LTR, and new viral particles are formed at the plasma membrane. Two copies of viral RNA assemble together with viral precursor proteins, which are subjected to processing by the viral protease. This results in maturation of the virion (Verma and Weitzman, 2005). 
Fig 2 Model of a retrovirus

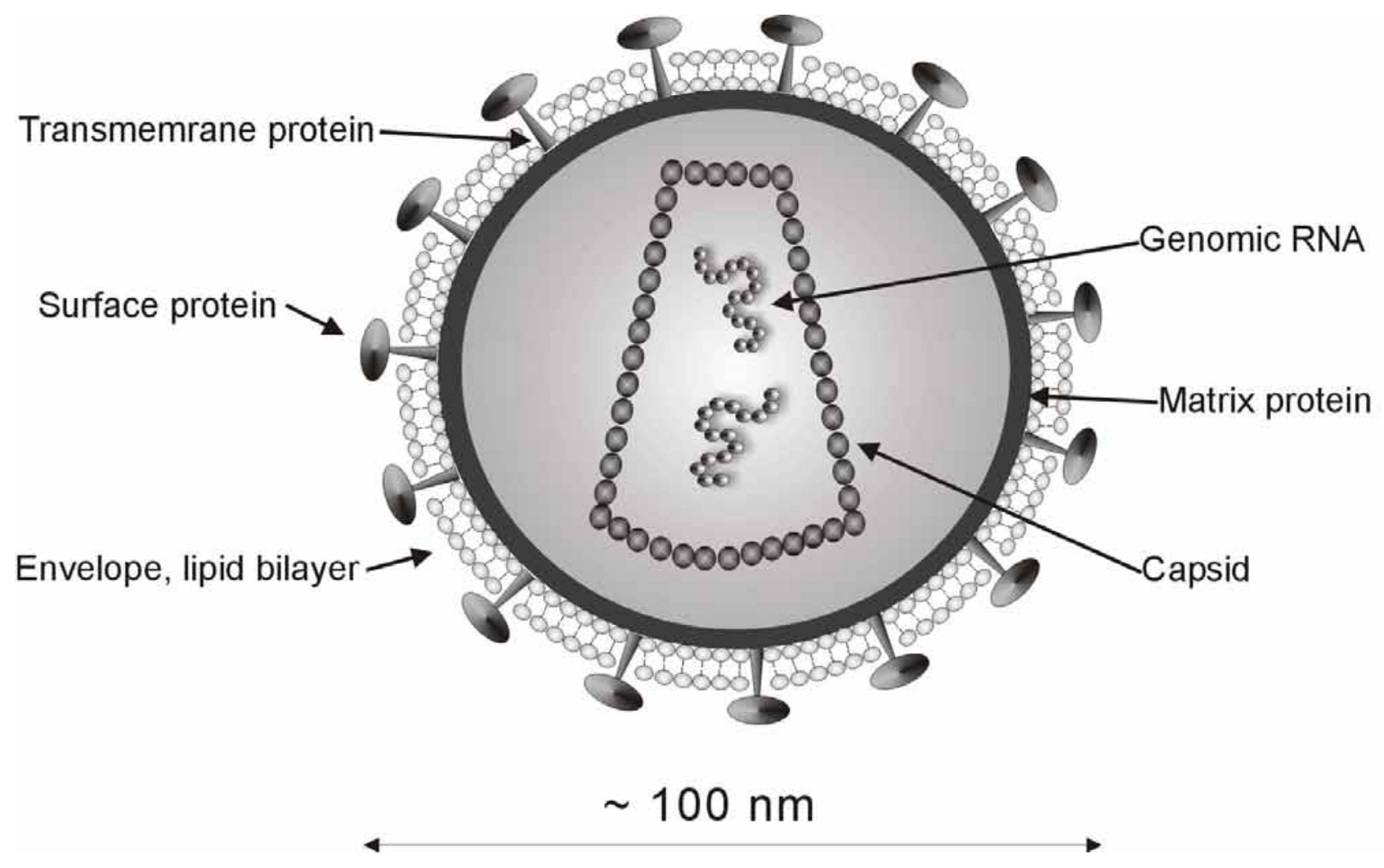




\subsubsection{Lentiviral vectors}

Lentiviruses encode up to six more proteins, compared to simple retroviruses, which contribute to virus replication and persistence of infection (Verma and Weitzman, 2005). They can transduce non-dividing cells (Naldini et al., 1996a), because of an active transport mechanism into the nucleus (Follenzi et al., 2000; Zennou et al., 2000). This is an important difference between lentiviruses and other retroviruses, since other retroviruses can only integrate when the host cells are actively replicating at the time point of infection (Miller et al., 1990). HIV-1 is the best studied lentivirus (Pfeifer, 2004) and most often used to design lentiviral vectors (Verma and Weitzman, 2005). HIV-1 derived vectors were found to favor genes as integration sites. It was suggested that integration may be promoted by increased chromatin accessibility in transcribed regions. Alternatively integration may be promoted at active genes by favorable interactions between HIV preintegration complexes (PICs) and locally bound transcription factors (Schroder et al., 2002).

Lentiviruses have been isolated from sheep (visna/maedi virus), goats (caprine arthritis encephalitis virus), cattle (bovine immunodeficiency virus), horses (equine infectios anemia virus, EIAV), cats (feline immunodeficiency virus, FIV), monkey (simian immunodeficiency virus), and humans (human immunodeficiency virus, HIV). The first report of transgenic mammals, created via lentiviral vectors, were published in 2002 (Lois et al., 2002; Pfeifer et al., 2002). Mouse embryos were infected at the zygote or morula stage with a HIV-derived SIN vector, carrying the GFP reporter gene. Both studies showed transgene integration, transgene expression and germ line transmission of viral gene constructs (Pfeifer, 2004). Lois et al. also showed the feasibility of lentiviral transgenesis in rats and demonstrated tissue-specific expression of GFP by using tissue-specific promoters in mice (Lois et al., 2002). The production of transgenic livestock by lentiviral vectors has been shown to be a less expensive alternative to $\mathrm{Ml}$ or NT, since GFP expressing pigs as well as GFP expressing cattle could be produced efficiently. In both species stable long-term expression and germline transmission occurred (Hofmann et al., 2003; Hofmann et al., 2004; Whitelaw et al., 2004). Lentiviral vectors are also suitable to create genetically modified birds. Transgenic chicken stably expressed a reporter gene up to the F2 generation (McGrew et al., 2004), and tissue-specific expression in birds was reported in quails, where Scott et al. demonstrated that the use of a GFP vector, 
driven by the human synapsin gene I promoter lead to the expression of GFP in neurons, which was persistent across multiple generations (Scott and Lois, 2005).

Many studies using lentiviral vectors for gene transfer have demonstrated unexpected high frequencies of transgenic animals expressing the transgene (Lois et al., 2002; Pfeifer et al., 2002; Hofmann et al., 2003; Hofmann et al., 2004; Whitelaw et al., 2004). Due to this fact, they suggested lack of gene silencing. But the analysis of the epigenetic regulation of individual integrants in lentiviral transgenic animals in vivo showed, that one-third of the proviruses exhibited only low or undetectable levels of expression and a high degree of methylation of CpG dinucleotides. This indicated that DNA hypermethylation played a role in lentivirus silencing in transgenic animals and that lentiviral transgenesis was affected by varying degrees of epigenetic modification (Hofmann et al., 2006).

For vector design, the viral genome is separated in two parts: the vector and the packaging constructs. The vector construct contains the LTRs, necessary cis-acting sequences and the transgene. The viral proteins essential for production of infectious particles are expressed in trans by the packaging cells (Pfeifer, 2004). The HIV-1 glycoprotein env has a highly restricted host range. It only infects cells containing CD4 and coreceptors. To broaden the host range of lentiviral vectors, they can be pseudotyped with the vesicular stomatitis virus glycoprotein (VSV-G) env, which is provided in trans by the packaging cell line, and imparts a wide tropism (Naldini et al., 1996).

To lower the possibility of an accidental activation of cellular oncogenes by random integration of the vector into the host genome, SIN-lentiviral vectors have been designed, in which the viral enhancer and promoter sequences within the LTRs have been deleted (Miyoshi et al., 1998).

The use of SIN vectors might also avoid gene silencing, because it was postulated that an active viral promoter sequence might attract the host silencing machinery to the integrated provirus (Pfeifer, 2004). Promoters, which have been used, are for example the human cytomegalovirus immediate early promoter (CMV) (Naldini et al., 1996), the promoter of the human phosphoglycerate kinase gene (PGK) (Follenzi et al., 2000), the human ubiquitin-C promoter (Lois et al., 2002), and the CAG promoter (a chicken beta-actin / CMV-compound promoter) (Pfeifer et al., 2002). Tissuespecific expression can be achieved by incorporating specific promoter sequences. For example, a lentiviral vector, containing the human keratin K14 promoter (LV-K14) 
was injected into porcine zygotes. Resulting LV-K14 transgenic animals expressed GFP specifically in basal keratinocytes of the skin (Hofmann et al., 2003) (Fig. 3).

The use of lentiviral vectors is limited by the size of the RNA genome. The maximal packaging capacity of an HIV-1 based vector particle is approximately $10 \mathrm{~kb}$, which restricts the size of the transgene plus internal promoter to less than $8.5 \mathrm{~kb}$.

The virus titer for successful viral transduction in embryos seems to be approximately $10^{9} \mathrm{lU} / \mathrm{ml}$ (Hofmann et al., 2003, Chan, Homan, et al. 1998 ).

Fig 3 Lentiviral vector

Carrying the K14 promoter (LV-K14, top). Arrow, self-inactivating mutation; eGFP, enhanced green fluorescent protein; LTR, long terminal repeat; ppt, polypurine tract;W, woodchuck hepatitis responsive element

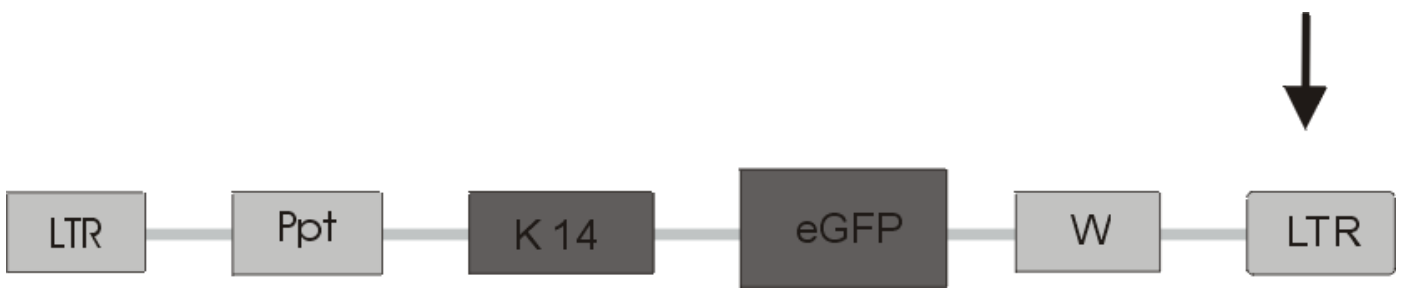




\subsection{In vitro production (IVP) of bovine embryos}

In vitro production of embryos includes collection of cumulus-oocyte complexes (COCs), maturation of COCs, capacitation of sperms, fertilization and subsequent culture of presumptive zygotes. All procedures happen in an artificial culture environment.

\subsubsection{History}

For IVF, the discovery that sperms have to undergo capacitation before fertilization was indispensable (Austin, 1951; Chang, 1951). In 1986, Parrish developed the so called swim-up method for capacitating bull sperm, which is still in use today (Parrish et al., 1986). The first calf from IVM and IVF was born in 1988 (Lu et al., 1988). Today routine protocols for bovine are widely established and allow the use of bovine embryo technologies, besides its classical use in animal breeding, as research tool for transgenesis (Galli et al., 2003).

\subsubsection{Recovery of ovaries and oocyte collection}

In common, ovaries for routine IVP procedures are obtained from a local abattoir. Transport medium, storage time and temperature must be taken into consideration (Gordon, 2003). PBS or $0.9 \%$ saline are generally used for the transport to the laboratory. Storage time is recommended within $1-2$ hours at a temperature of $30^{\circ} \mathrm{C}$ (Gordon, 2003), but no adverse effect on developmental competence of oocytes was found at storage times up to $12 \mathrm{~h}$ at temperatures from 15 to $21^{\circ} \mathrm{C}$ (Schernthaner et al., 1997).

For oocyte collection, dissection of intact antral follicles $(2-8 \mathrm{~mm})$ and their subsequent carefully controlled rupture was established in the 1980s. This technique allowed recovery of more high quality oocytes with the least disruption of the surrounding cumulus cells than aspiration (Gordon, 2003).

Aspiration of follicles has been most commonly employed method since it has been shown to be three times faster than dissection. Bovine follicles were aspirated with $18-22 \mathrm{~g}$ needles and $3-20 \mathrm{ml}$ syringes or with $16-19 \mathrm{~g}$ needles attached to a vacuum pump using pressures of $75-100 \mathrm{mmHg}$ (Gordon, 2003). Using a $17 \mathrm{~g}$ 
needle with $55 \mathrm{~mm} \mathrm{Hg}$ resulted in the highest number of viable oocytes because a reduction of pressure reduces the rate of oocytes, which are stripped of cumulus cells (Fry et al., 1997).

Slicing, cutting and dissection of the bovine ovary for recovering immature oocytes can be combined with ovary slicing. Many authors recommend the use of ovary slicing, since oocyte yield could be more than doubled in comparison to aspiration (Gordon, 2003). This is due to the fact that even follicles located under the ovarian surface are collected as well, whereas during aspiration only oocytes from follicles at the surface are collected. It was shown that developmental competence of oocytes increased with their size, and oocytes with the largest diameters were found at the follicles at the surface of the ovary and collected by aspiration (Arlotto et al., 1996).

\subsubsection{Assessing oocyte quality}

One example for selection of oocytes for IVM by morphological parameters is shown in Table 2. This method is used by many groups (Hazeleger et al., 1995; Khurana and Niemann, 2000; de Wit and Kruip, 2001), although a broad variety of more detailed classifications can be found (Gordon, 2003). It could be shown that most class I oocytes were at the GV stage and showed higher blastocyst formation after fertilization than oocytes of lower quality classes (Cetica et al., 1999).

Table 2 Criteria used to classify bovine oocytes

\begin{tabular}{lll}
\hline Class & \multicolumn{1}{c}{ Cumulus Cells } & \multicolumn{1}{c}{ Cytoplasm } \\
\hline I & $>5$ dense layers of cumulus cells & even, dense, finely granulated \\
II & $3-5$ dense layers of cumulus cells & $\begin{array}{l}\text { finely granulated to moderate } \\
\text { size granulated }\end{array}$ \\
III & $\begin{array}{ll}\text { few layers of cumulus cells with } \\
\text { gaps }\end{array}$ & granulated and irregular \\
IV & denuded & small, granulated and irregular
\end{tabular}

Besides cumulus cells, constituents of the follicular fluid and their concentrations have shown to be useful for assessing oocyte quality. In addition to morphological 
parameters, progesterone, estradiol-17ß and insulin-like growth factor-I (IGF-I) concentrations were measured in the follicular fluid of each follicle and attempts were made to find a correlation with the developmental competence of the oocyte. It could be shown that the progesterone content of the follicular fluid was lower when it contained well developing oocytes (Hazeleger et al., 1995). Another study demonstrated that the estradiol-17 $\beta$ content of high quality follicles should be above $100 \mathrm{pg} / \mathrm{ml}$ (Araki, 1998).

One more parameter to define the developmental competence of bovine oocytes is their diameter. Oocytes smaller than $110 \mu \mathrm{m}$ are still transcriptionally active and have a reduced ability to resume meiosis (Lechniak et al., 2002).

\subsubsection{Oocyte maturation}

In mammalian species such as the cow, some hours before the rupture of the follicle and ovulation, the fully grown oocyte in the preovulatory follicle resumes meiosis, progressing from prophase of the first meiotic division to metaphase II. This maturation process, which is accompanied by complex changes in the protein phosphorylation pattern (Tomek et al., 2002), transforms the primary oocyte into a mature secondary oocyte. This includes a series of modulations of organelles and inclusions, as well as a period of active transcription, which is necessary for the oocyte to achieve meiotic and developmental competence (Hyttel et al., 1997). Oocyte transcription, including nucleolus function with ribosomal RNA syntheses, is activated in the secondary follicle and is maintained up to an oocyte diameter of about $110 \mu \mathrm{m}$ in the $3 \mathrm{~mm}$ tertiary follicle (Hyttel et al., 1997). In the dominant follicle, full developmental competence is reached during the final maturation, initialized by the preovulatory LH surge, which occurs $24 \mathrm{~h}$ prior ovulation.

The final maturation can be classified into nuclear and cytoplasmic maturation. Four 8 hours after the LH surge germinal vesicle breakdown occurs, which is a $\mathrm{Ca}^{2+}$ dependant process (He et al., 1997), and is characterized by gradual chromatin condensation, the disappearance of a compact nucleolus and nuclear membrane disintegration. This is the beginning of nuclear maturation. Then, chromosomes condense into a compact form and arrange themselves on the equatorial plate of the meiotic spindle, and the first meiotic division is completed by extrusion of the first polar body. Meiosis progresses to metaphase II, but is not completed unless sperm penetration occurs. Two kinases play important roles in the nuclear maturation: 
maturation-promoting factor (MPF) and mitogen-activated protein (MAP) kinase, which is necessary for metaphase II arrest (Gordo et al., 2001).

During cytoplasmic maturation, cortical granules align along the oolemma, mitochondria are rearranged, the lipid content increases to provide energy during maturation and early embryonic development (Kim et al., 2001), the Golgi compartment is reduced and ribosomes are redistributed (Hyttel et al., 1997).

During final maturation, the follicle itself undergoes a series of changes. The membrane granulosa cells stop synthesizing estradiol and a marked increase in progesterone synthesis together with an extensive expansion of the cumulus cells can be observed. The extensions of the corona radiata cells, which penetrate the ZP, are retracted, indicating that communication between the oocyte and its surrounding support cells decreases after the onset of final maturation (Gordon, 2003).

In response to the LH surge, cumulus cells secrete hyaluronic acid, a non-sulphated glycosaminoglycan bound to the cumulus cells by linker proteins. During cumulus expansion the hyaluronic acid becomes hydrated and the cumulus cells are embedded in a mucified matrix. This process is called mucification. Both, expansion and mucification of cumulus cells are regulated by oocyte-secreted factors. After ovulation, the oocyte actively participates in degradation of the cumulus matrix (Gilchrist et al., 2004) and leaves herself within a few hours naked in the oviduct.

To achieve oocyte maturation in vitro, the first step required is selection of appropriate COCs (see above). Culture media used in cattle IVM are usually bicarbonate-buffered systems containing basic physiological saline with the addition of pyruvate, lactate and glucose. Different ion concentrations and levels of energy are in use. The media are usually supplemented with serum or albumin and antibiotics. More complex media contain amino acids, vitamins, purines, hormones, growth factors, cytokines or steroids. A 24-hour culture period has been regarded to be sufficient for the completion of nuclear maturation (Gordon, 2003).

Criteria for evaluating the quality of the oocytes after maturation are the extrusion of the first polar body, which should have taken place in about $80-90 \%$ of the oocytes after a 24 hour maturation period (Gordon, 2003).

Another aspect for assessing the quality of maturation is the degree in cumulus expansion as shown in Table 3 (Hunter and Moor, 1987). 
Table 3 Degrees of cumulus cell expansion

\begin{tabular}{|c|c|}
\hline $\begin{array}{c}\text { Grade 1: full cumulus } \\
\text { cell expansion }\end{array}$ & $\begin{array}{c}\text { extremely adhesive nature and enlargement of the cumulus } \\
\text { cells, at least x 3 oocyte diameters }(>300 \mu \mathrm{m}) \text { away from the } \\
\text { ZP }\end{array}$ \\
\hline $\begin{array}{c}\text { Grade 2: moderate } \\
\text { cumulus cell expansion }\end{array}$ & $\begin{array}{c}\text { expansion of the cumulus cells } \times 2 \text { diameters }(>200 \mu \mathrm{m}) \text { away } \\
\text { from the ZP }\end{array}$ \\
\hline $\begin{array}{c}\text { Grade 3: slight cumulus } \\
\text { cell expansion }\end{array}$ & cumulus cells are tightly adherent to the ZP \\
\hline
\end{tabular}

Furthermore the distribution of mitochondria gives information about the quality of the maturation process (Bavister, 2000). Various staining methods together with confocal microscopy and ultrastructural analyses revealed more detailed information about processes in the maturing oocyte (Gordon, 2003).

\subsubsection{In vitro fertilization (IVF)}

Fertilization includes capacitation and acrosome reaction of sperms, fusion of gametes and development of pronuclei. Oocytes must have reached metaphase II of the second meiotic division.

Capacitation includes a number of reversible chemical reactions, which remove epidydimis derived proteins, to allow the sperm for penetration of the oocyte (Gordon, 2003). Presence of extra-cellular $\mathrm{Ca}^{2+}$ is essential for the reaction and addition of heparin, a glucosaminoglycan, to the capacitation medium allows capacitation in vitro (Mahmoud and Parrish, 1996). During capacitation an increase in motility of the sperm tail can be observed. This so called hyperactivation is as well $\mathrm{Ca}^{2+}$ dependent and may facilitate the penetration of the cumulus matrix of the oocyte (Ho and Suarez, 2001).

During the acrosomal reaction the outer acrosomal membrane of the sperm amalgamates with the overlying plasma membrane, to allow the dispersal of acrosomal contents. This is essential for penetration of the ZP (Gordon, 2003).

Penetration of the sperm activates the oocyte, which accomplishes the second meiotic division. Furthermore this activation induces several changes in the cytoplasm of the oocyte, such as the influx of calcium, which allows release of the 
cortical granules to prevent penetration of more sperms. This activation enables the oocyte to develop pronuclei and form a zygote.

To prepare semen for fertilization in vitro and select only highly motile sperms, several methods were developed to ensure appropriate capacitation and acrosome reaction. Bovine IVP is usually performed with frozen-thawed semen from Al stations. This ensures a high standard of semen quality (Gordon, 2003).

The swim up procedure was developed 1986 by Parrish et al. (Parrish et al., 1986), where frozen-thawed sperm is placed at the bottom of a tube and covered with TALP medium. During $1-2$ hours of incubation time motile sperms swim upwards and undergo capacitation and acrosome reaction. After one or two washing steps with fresh TALP medium the sperm suspension is ready for use. Another regularly used method is the Percoll gradient-based separation of motile sperms, developed by Gorus et al. (Gorus and Pipeleers, 1981). The method consists of the filtration of semen through an isotonic Percoll layer and subsequent centrifugation of the cell pellet on a preformed continuous Percoll gradient. After fractionation of the density gradient, immotile spermatozoa are recovered at lower density, whereas an increase in progressive velocity is measured for spermatozoa collected at higher densities.

Media used for IVF are for example the TALP medium, which is a modified Tyrode preparation containing $25 \mathrm{mM}$ sodium bicarbonate and BSA. It is further modified with varying amounts of energy sources (Gordon, 2003). Furthermore modified SOF, which is supplemented with essential amino acids, non-essential amino acids, glutamine and glycine, is in use for bovine IVF (Gordon, 2003). Coincubation times of oocytes and sperm vary between 18 and 24 hours. Rehmann et al (Rehman et al., 1994) found that a 24 hour period of co-incubation of cattle oocytes and frozen thawed sperm resulted in the highest fertilization rates, but they were significantly lower for shorter periods of $4-12$ hours.

\subsubsection{In vitro culture (IVC)}

Culture of presumptive bovine zygotes was, until the 1980 s, only possible up to the 8 - 16 cell stage, where development stopped (Eyestone et al., 1987). This so called 8cell block could be overcome by co-culture of the early embryos with bovine oviduct epithelial cells (Eyestone et al., 1987). The development of cell free, conditioned media followed, where only the supernatant of cultured cells was used to cultivate bovine embryos to the blastocyst stage (Eyestone and First, 1989). 
Synthetic oviduct fluid (SOF) was originally based on the biochemical analysis of ovine oviductal fluid, but was subsequently modified by the addition of amino acids (Gordon, 2003). Today, SOF is one of the media widely used for bovine embryo culture in vitro.

Current efforts tend to develop chemically defined protein free media. Reports started at 1991, where it could be shown that blastocyst formation was possible in chemically defined protein free medium (Pinyopummintr and Bavister, 1991). Until today blastocyst rates of these culture systems remain low (Oyamada and Fukui, 2004).

\subsubsection{Zona pellucida}

\subsubsection{Structure and function:}

The proteins of the zona pellucida are synthesized by the oocyte and the granulosa cells to form an extra-cellular-matrix (ECM) of concentric layers consisting of crosslinked zona proteins $1-3$ (Herrler and Beier, 2000). Zona protein 2 and 3 form filaments of repeating heterodimers which are cross-linked by dimeric zona protein 1 (Fig 4.) (Green, 1997). All ZP proteins are sulfated glycoproteins (Green, 1997). The ZP induces sperm-oocyte interaction, acrosome reaction and prevents polyspermy. It also prevents disaggregation of the noncompacted blastomeres and the premature attachment to the oviductal end endometrial surface. It protects the embryo against toxins, bacteria, viruses and phagocytes (Herrler and Beier, 2000). After fertilization, hardening of the ZP occurs, which is the result of the formation of disulfide linkages together with specific proteolysis (Iwamoto et al., 1999).

Fig 4 Two dimensional structure of the zona pellucida
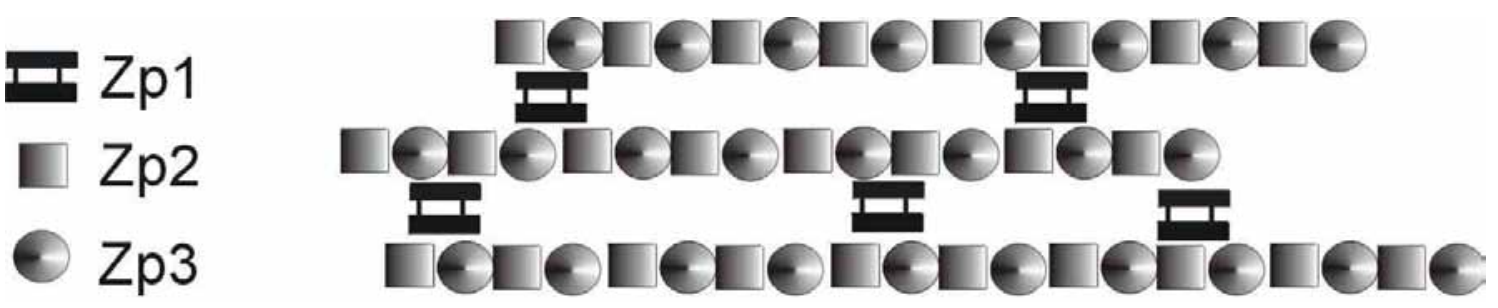


\subsubsection{Drilling the ZP}

Undesired ZP hardening could be induced by in vitro culture and may hamper implantation (De Vos and Van Steirteghem, 2000).

To overcome this problem, some authors recommend zona drilling (De Vos and Van Steirteghem, 2000). Beside that aspect, some other biotechnological applications, such as ICSI, blastomere biopsy or polar body biopsy, also require a hole in the ZP, its partial or total removal. Chemical removal or thinning of the ZP is usually performed with Tyrode's acid or pronase, which exhibit embryos to additional stress, such as changes in $\mathrm{pH}$ or osmolarity. Mechanically drilled holes by a needle require high technical skills to achieve holes of reproducible size and shape without hurting the oocyte or embryo (Herrler and Beier, 2000). Various reports in the literature demonstrate the feasibility of laser-assisted zona drilling (Herrler and Beier, 2000).

\subsubsection{Cumulus cells}

\subsubsection{In vivo}

Although numerous data on the physiological pathways by which the cumulus oophorus influences oocyte maturation and ovulation are available, its exact function during mammalian fertilization still needs to be identified (Tanghe et al., 2003a). The beneficial effects of cumulus cells during the fertilization process of cattle can be explained by: 1) attracting, trapping and selecting sperm, 2) faciliating sperm capacitation, acrosome reaction and penetration or by 3 ) preventing precocious hardening of the ZP. It is known that a bovine oocyte is ovulated with a covering of expanded cumulus cells and that these cells are dispersed within the ampulla of the oviduct within only few hours after ovulation (Lorton and First, 1979). Therefore the oocyte is probably fertilized cumulus free, but cumulus cells in the immediate vicinity of the oocyte create a microenvironment that is favourable for fertilization (Hunter, 1998).

\subsubsection{In vitro}

Unlike in vivo, the cumulus cells are tightly attached to the in vitro matured oocyte (Park et al., 1989). Several studies confirm that removal of cumulus cells strongly decreases developmental capacity (Cox et al., 1993; Zhang et al., 1995). But 
denuding oocytes before fertilization is necessary for some micromanipulation techniques such as microinjection, or to evaluate morphological aspects of oocyte quality, such as polar body extrusion, cytoplasm morphology of the oocyte or the extent of the perivitelline space. Furthermore cumulus cells must be removed when oocyte-sperm interactions are studied (Tanghe et al., 2003). 


\subsection{Laser application}

\subsubsection{Presumptions for the ideal laser}

It should provide a touch-free objective-delivered accessibility by the culture dish and the aqueous medium.

The laser should be affordable and easily adapted to any existent inverted microscope.

The laser target interaction process should be controlled accurately and produced the ZP opening with no mechanical, thermal or mutagenic side effects (Germond et al., 1995).

\subsubsection{Lasers emitting at the UV spectrum $(10-380 \mathrm{~nm})$}

Tadir et al. (1991) were the first who used a solid-state ultraviolet laser (Nd :YAG, wavelength $1064 \mathrm{~nm}$ ) for drilling the ZP. But the resulting damage in the ZP was quite inconsistent. ArF-excimer laser emtting at $193 \mathrm{~nm}$ was first reported to allow ZP drilling of mouse oocytes with no detectable heating or structural damage of the surroundings (Palanker et al., 1991). Emitting in UV-spectrum this cold light laser was strongly absorbed by water and had a penetration depth of $<1 \mu \mathrm{m}$. This required a wave guide, e.g. an airfilled micropipette, to touch the ZP directly for drilling.

Neer et al. studied longer wavelengths (266 nm, 308 nm, 366 nm, 532 nm), which were less absorbed by water and enabled a non-touch mode to drill holes in ZPs. These authors concluded, that a $308 \mathrm{~nm}$ XeCl-excimer laser was best suited to induce photoablation of ZPs (Neer et al., 1992). After drilling a tangential trench in the ZP of mouse oocytes, fertilization rate significantly improved after fertilization with sperm of long time vasectomized mice (el Danasouri et al., 1993). But using wavelengths in the UV spectrum, has dangerous effects on DNA. The absorption maximum for DNA is $266 \mathrm{~nm}$ and lasers operating close to this wavelength could not exclude a possible harm to genetic structures (Ebner et al., 2005). Therefore the possible cytotoxicity and mutagenicity excluded lasers, working in the UV spectrum, from IVP procedures (Kochevar, 1989). 


\subsubsection{Lasers emitting at the infrared spectrum $(780 \mathrm{~nm}-50 \mu \mathrm{m})$}

Strong light absorption bands by water are also exhibited in the infrared spectrum. The erbium-yttrium aluminium garnet (YAG) laser with $2.9 \mu \mathrm{m}$ wavelength is close to the strongest water absorption peak. The laser beam is guided through a quartz fiber and is brought into direct contact with the zona pellucida. In human assisted reproduction it has been shown to be save and efficacious. Births of healthy babies were reported after drilling the ZPs of oocytes prior fertilization (Antinori et al., 1994) and ultrastructural examination of human unfertilized oocytes and preimplantation embryos showed no damage of the underlying oolemma (Obruca et al., 1997).

A laser system which does not require direct contact to the oocyte, is the $1.48 \mu \mathrm{m}$ diode laser beam. It also operates in the infrared spectrum of light but is focused through a microscope objective, which allows a nontouch microdrilling of the ZP while maintaining a high degree of accuracy under conventional culture conditions (Rink et al., 1996). SEM images demonstrate high quality of the drilling mode since the drilled trench has a precise cylindrical shape with a smooth surface and regular incision edges (Germond et al., 1995b; Rink et al., 1996). 


\section{Material and Methods}

\subsection{Virus production}

The self inactivating (SIN) lentiviral vector, which carries the eGFP reporter gene under the control of the human phosphoglycerate kinase (PGK) promoter, was produced as recently described (LV-PGK; (Hofmann et al., 2003)). In brief, lentiviral particles were produced by transient transfection of packaging cells. The viral particles were concentrated as previously described (Pfeifer et al., 2002b). Virus titer was measured by FACScan analysis (Becton-Dickinson, New Jersey, USA) of infected HEK293T cells. Virus titer is indicated in infectious units $/ \mathrm{ml}(\mathrm{IU} / \mathrm{ml})$, which represents the number of infectious viral particles $/ \mathrm{ml}$.

\subsection{In vitro production of bovine embryos}

Unless otherwise indicated, all chemicals were purchased from Sigma-Aldrich (Steinheim, Germany) and all procedures were performed at $39^{\circ} \mathrm{C}$. All media were equilibrated in the incubator at maximum humidity, $39^{\circ} \mathrm{C}$, and $5 \% \mathrm{CO}_{2}$ in air or in $5 \%$ $\mathrm{CO}_{2}, 5 \% \mathrm{O}_{2}, 90 \% \mathrm{~N}_{2}$ for at least 90 min prior use.

Ovaries were collected at a local slaughterhouse and transported to the laboratory at $25^{\circ} \mathrm{C}$ in phosphate-buffered saline (PBS). Cumulus-oocyte-complexes (COCs) were obtained by aspiration of 3 - $8 \mathrm{~mm}$ follicles. COCs with complete and dense layers of cumulus cells were selected for in vitro maturation and randomly distributed to the different treatment groups. Selected COCs were washed three times in maturation medium MPM (modified Parker medium), supplemented with 10\% estrous cow serum (ECS), 0.025 units $/ \mathrm{ml}$ follicle-stimulating hormone (FSH; Sioux Biochemical, Inc., Sioux Center, USA) and $0.0125 \mathrm{U} / \mathrm{ml}$ luteinizing hormone (LH; Sioux Biochemical, Inc.) at room temperature. Groups of 35 - 40 oocytes were transferred to 4-well plates (Nunc, Roskilde, Denmark) with $400 \mu \mathrm{l} \mathrm{MPM}$ and maintained for $19-20 \mathrm{~h}$ at $39^{\circ} \mathrm{C}$ in an atmosphere of $5 \% \mathrm{CO}_{2}$ in humidified air.

Before $\mathrm{MD}$ or $\mathrm{Ml}$, cumulus cells were removed from oocytes by vortexing for $3 \mathrm{~min}$ in modified PBS (mPBS; PBS supplemented with $3 \mathrm{mg} / \mathrm{ml} \mathrm{BSA}$ and $50 \mu \mathrm{g} / \mathrm{ml}$ gentamicin) containing $4 \mathrm{mg} / \mathrm{ml}$ hyaluronidase. If oocytes were not completely denuded, remnant cumulus cells were removed by gentle pipetting. Afterwards, the 
denuded oocytes were washed three times in fresh mPBS (without hyaluronidase). Only oocytes showing a dense, evenly granulated cytoplasm were selected for further treatment.

Matured COCs or treated denuded oocytes were washed three times in fertilization medium Fert Talp (Tyrode albumin lactate pyruvate) supplemented with sodium pyruvate $(2.2 \mathrm{mg} / \mathrm{ml})$, heparin sodium salt $(2 \mathrm{mg} / \mathrm{ml})$, BSA $(6 \mathrm{mg} / \mathrm{ml})$ and transferred to 400- $\mu$ d droplets of Fert Talp in groups of 35 - 40. Frozen-thawed spermatozoa were subjected to the swim-up procedure for 90 min (Parrish et al., 1986b). Afterwards, COCs or treated oocytes were co-incubated with spermatozoa $\left(1 \times 10^{6}\right.$ cells $\left./ \mathrm{ml}\right)$ in the same medium for $18 \mathrm{~h}$ at $39^{\circ} \mathrm{C}$ in a humidified atmosphere of $5 \% \mathrm{CO}_{2}$ in air. Presumptive zygotes were denuded by vortexing in mPBS supplemented with 4 $\mathrm{mg} / \mathrm{ml}$ hyaluronidase and washed three times in synthetic oviduct fluid (SOF) medium enriched with 10\% ECS, 4\% 50x BME (Basal Medium Eagle) and 1\% 100x MEM (Minimum Essential Medium).

After treatment (MI or MD), zygotes were washed three times in SOF, transferred in $400-\mu l$ droplets of culture medium, and maintained for 8 days in an atmosphere of $5 \%$ $\mathrm{CO}_{2}, 5 \% \mathrm{O}_{2}$, and $90 \% \mathrm{~N}_{2}$ at $39^{\circ} \mathrm{C}$ and maximum humidity. Sham-treated zygotes (MI of buffer or MD without incubation in virus suspension) which were cultured under the same conditions, served as controls.

\subsection{Subzonal virus injection}

Concentrated lentivirus ( $100 \mathrm{pl}, 2.5 \times 10^{9} \mathrm{IU} / \mathrm{ml}$ ) was injected into the perivitelline space of oocytes or zygotes through a heat pulled glass capillary without damaging the plasma membrane as previously described (Fig. 5; (Hofmann et al., 2003a; Hofmann et al., 2004)). 
Fig 5 Subzonal microinjection of a bovine oocyte

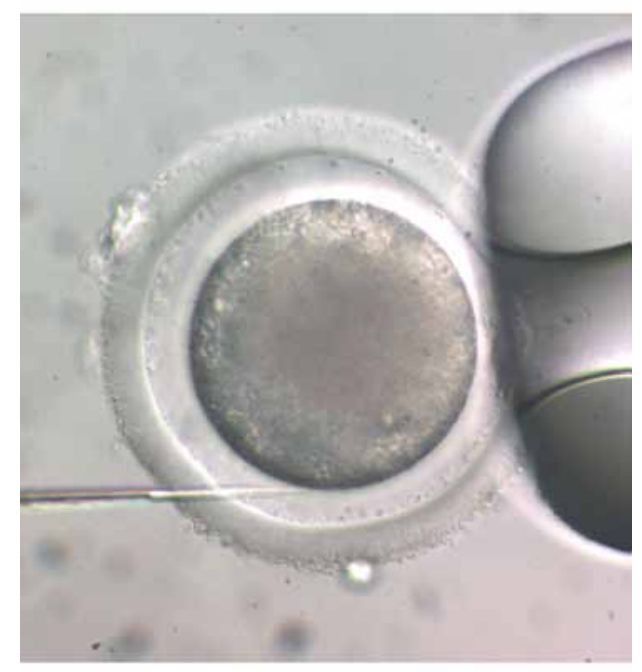

\subsection{Microdrilling and virus coincubation}

MD of denuded oocytes or zygotes (groups of 20 - 30) was performed in $40-\mu l$ droplets of mPBS, covered with mineral oil in a 3.5-cm petri dish (Nunc, Roskilde, Denmark). Laser beams were generated by a diode laser (wavelength of $1.48 \mu \mathrm{m}$ ) using an Octax Laser Shot ${ }^{\mathrm{TM}}$ system mounted on a light microscope (Axiovert 100; Zeiss, Göttingen, Germany). Laser beams of $3 \mathrm{~ms}$ were directed tangentially against the ZP three or four times to create an opening larger than $40 \mu \mathrm{m}$ (Schmoll et al., 2003) (Fig. 8). The hole was generated close to the polar body, where the space between oolemma and ZP has the largest diameter (Fig. 6). 
Fig 6 Microdrilled bovine ooycte

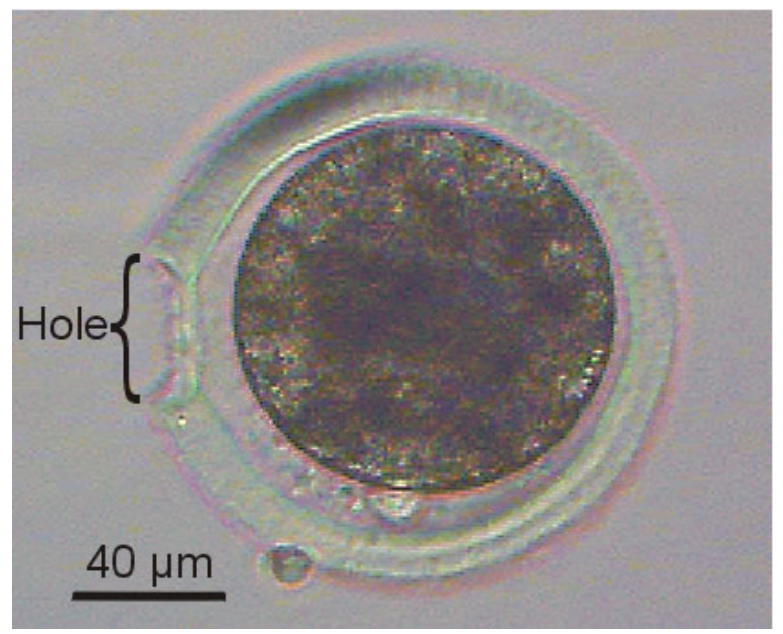

After MD, oocytes and zygotes were washed three times in Fert Talp and SOF, respectively. For transduction of oocytes and zygotes $0.5 \mu \mathrm{l}$ of concentrated virus stock $\left(2.5 \times 10^{9} \mathrm{IU} / \mathrm{ml}\right)$ was added to $20-\mu \mathrm{l}$ droplets of the respective culture medium (Fert Talp for oocytes, SOF for zygotes), which were covered with mineral oil. After incubation $\left(39^{\circ} \mathrm{C}, 5 \% \mathrm{CO}_{2}\right.$ in humidified air) for $4 \mathrm{~h}$, oocytes and zygotes were washed at least six times in fresh medium to remove remaining virus.

The time schedule for treatment of oocytes and zygotes is outlined in Fig. 7. The period for microdrilling and virus coincubation or virus injection was before the fertilization period in the oocyte groups and after fertilization in the zygote groups. Thus, fertilization was started 24 - $25 \mathrm{~h}$ and 19 - $20 \mathrm{~h}$ after onset of oocyte maturation in the oocyte and zygote treatment groups, respectively. The duration of maturation, fertilization and culture was the same for oocytes and zygote treatment groups. 
Fig 7 Treatment schedule for oocytes and zygotes

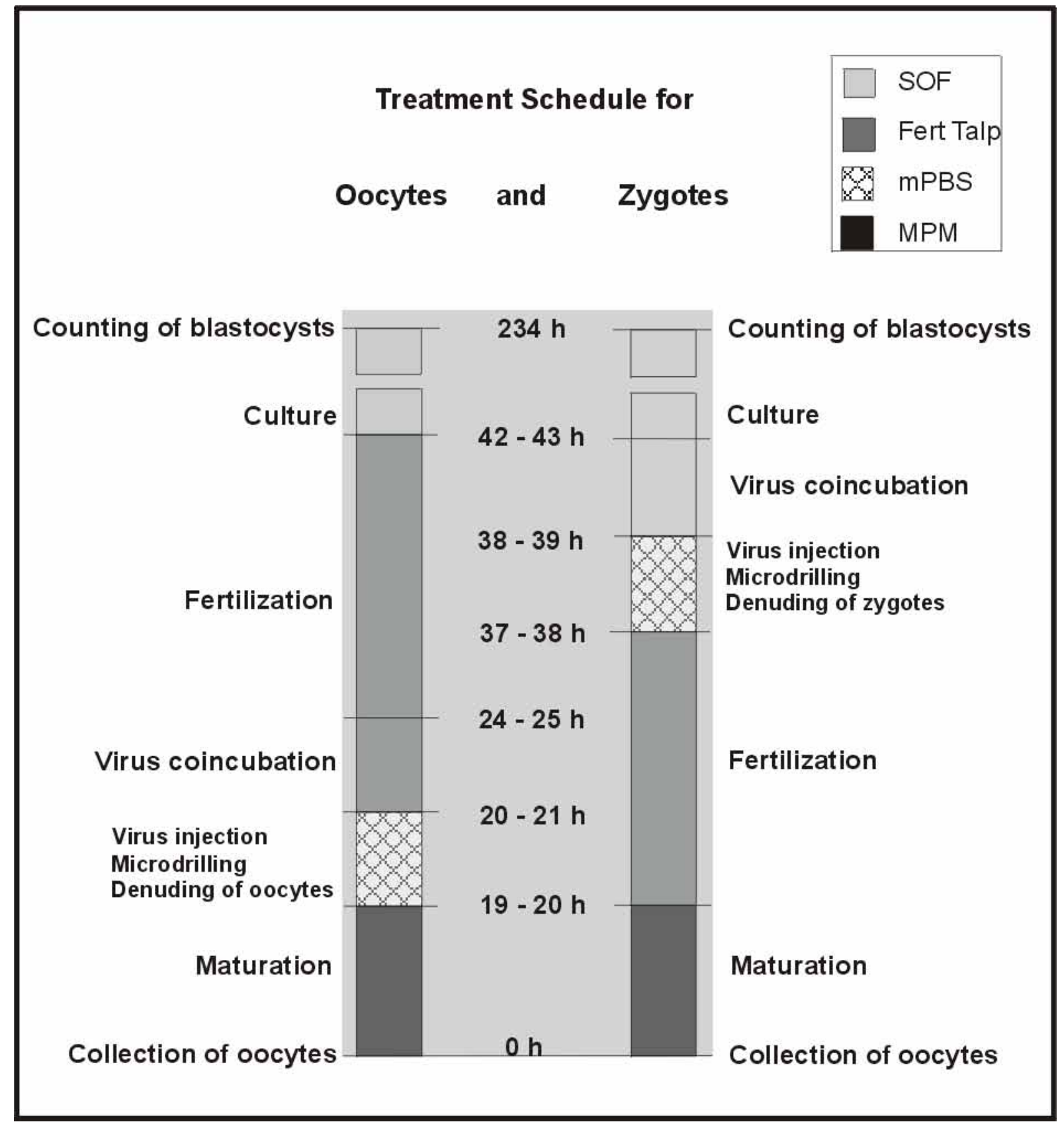


Fig 8 Schematic diagram of the microdrilling procedure

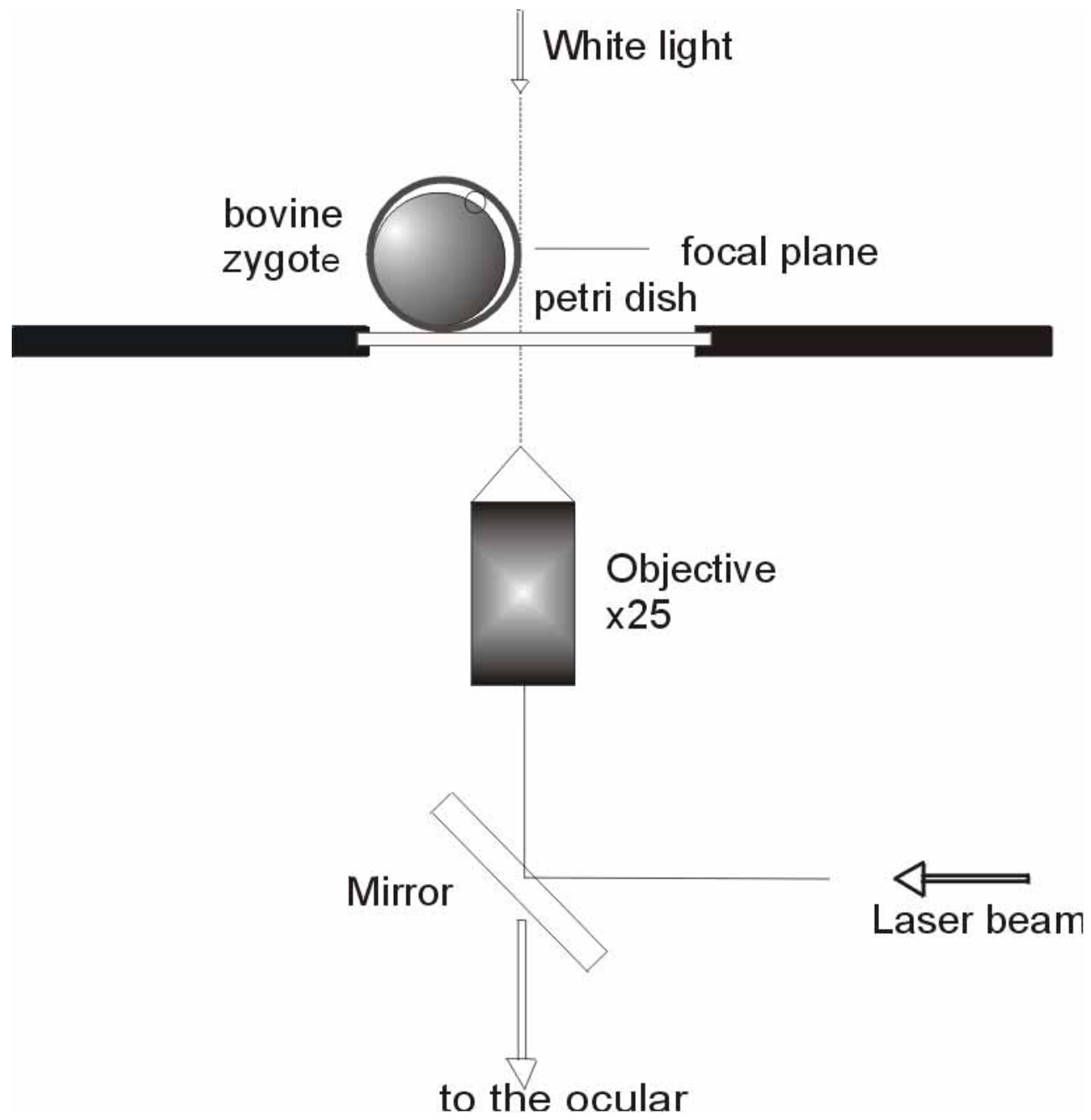

\subsection{Effect of treatment and developmental stage}

Expression of eGFP in blastocysts was visualized using an inverted microscope (Axiovert 200; Zeiss) with eGFP specific filter (\# 13; Zeiss) and documented with a digital camera (Axio Cam; Zeiss). Blastocyst morphology was evaluated on day 8 on brightfield images. MI and MD experiments were performed on the same day, by the same operator and with the same batch of oocytes or zygotes. 


\subsection{Determination of polyspermy rate}

To assess, if perforation of the ZP enhances polyspermy, pronuclear formation in zygotes was analyzed by orcein staining. MD oocytes were incubated with $10^{6}$ spermatozoa/ml for $18 \mathrm{~h}$ or for $4 \mathrm{~h}$, or with $0.5 \times 10^{6}$ spermatozoa $/ \mathrm{ml}$ for $8 \mathrm{~h}$. A control group of denuded oocytes with an intact ZP was incubated with $10^{6}$ spermatozoa/ml for $18 \mathrm{~h}$. Afterwards, presumptive zygotes were immobilized between a slide and a cover slip and fixed for at least $24 \mathrm{~h}$ in ethanol/acetic acid (3/1). After fixation, orcein solution $(0.75 \%)$ was dropped under the cover slip and pronuclei were counted immediately.

\subsection{Statistics}

Cleavage rates, blastocyst rates and rates of eGFP positive blastocysts were analyzed by the General Linear Models (GLM) procedure using the SAS program version 8.2 (SAS Institute Inc., Cary, NC, USA). The following model was used to estimate effects of treatment (MI vs. MD) and developmental stage (oocyte vs. zygote):

$$
Y_{i j k l}=\mu+\text { stage }_{i}+\text { treat }_{j}+\text { virus }_{k}+\varepsilon_{i j k l}
$$

with:

$\mathrm{Y}_{\mathrm{ijk}}=$ an observation for cleavage rate, blastocyst rate, expression rate for record $\mathrm{ijk}$; $\mu=$ expected mean of $Y ;$ stage $_{i}=$ fixed effect of stage $i, i=1$ (oocyte) and 2 (zygote); treat $_{\mathrm{j}}=$ fixed effect of treatment $\mathrm{j}, \mathrm{j}=1$ (microdrilling) and 2 (subzonal injection); virus = fixed effect of virus application I, I = 1 (sham treatment) and 2 (virus treatment); $\varepsilon_{\mathrm{ijkl}}$ $=$ random error term associated with record 1 to 22 on stage $\mathrm{i}$ with treatment $\mathrm{j}$ and treatment with virus I. $\mathrm{P}<0.05$ was considered significant. 


\section{Results}

\subsection{Effects on embryonic development}

Early cleavage $(p<0.05)$ and blastocyst rates $(p<0.01)$ were significantly affected by the stage (oocyte vs. zygote) at which manipulation was performed (Table 4). Cleavage rates were higher when zygotes were manipulated (Table 5). Within both treatment groups ( $\mathrm{Ml}$ or $\mathrm{MD}$ ), blastocyst rates were higher when virus or sham treatment was performed at the zygote stage (Table 5). Interestingly, the type of manipulation (MI vs MD) did not affect cleavage rates, but had a significant effect on blastocyst rates $(\mathrm{p}<0.001$; Table 4$)$. After Ml of virus or buffer, higher blastocyst rates were observed than after $\mathrm{MD}$, both in the oocyte and zygote treatment groups (Table 2). To clarify if a hole in the ZP per se hampers development of bovine embryos, we performed mechanical slicing of the ZP at the zygote stage, opening about one third of the ZP and thus creating a bigger hole as compared to the MD technique. ZP slicing did not decrease development to blastocyst $(26 \% ; 6 / 23)$ as compared to non-sliced control zygotes $(25 \% ; 4 / 16)$. The viral vectors and interactions between the various parameters (treatment $x$ virus; stage $x$ virus) did not influence development of oocytes or zygotes (Table 4)

\subsection{Effects on transgene expression}

The proportion of eGFP expressing blastocysts was affected by stage $(p<0.05)$, virus $(p<0.001)$ and interaction of stage $x$ virus $(p<0.05)$ (Table 4$)$. A higher proportion of eGFP expressing blastocysts was observed when oocytes were infected (Table 5).

Overall efficacy, i.e. the number of eGFP expressing blastocysts per total number of infected oocytes or zygotes, respectively, was influenced by treatment $(p<0.05)$, virus $(p<0.001)$ and the interaction of treatment $x$ virus $(p<0.05)$ (Table 4). Injection of lentiviral particles into the perivitelline space of oocytes resulted in the highest proportion of eGFP expressing blastocysts (Table 5). Representative images of infected bovine blastocysts and negative control (bottom) are shown in Fig. 9. Bright field (left), fluorescence images (right). 
Fig 9 Analysis of eGFP expression in blastocysts after lentiviral gene transfer. Representative images of infected bovine blastocysts and negative control (bottom). Bright field (left), fluorescence images (right).
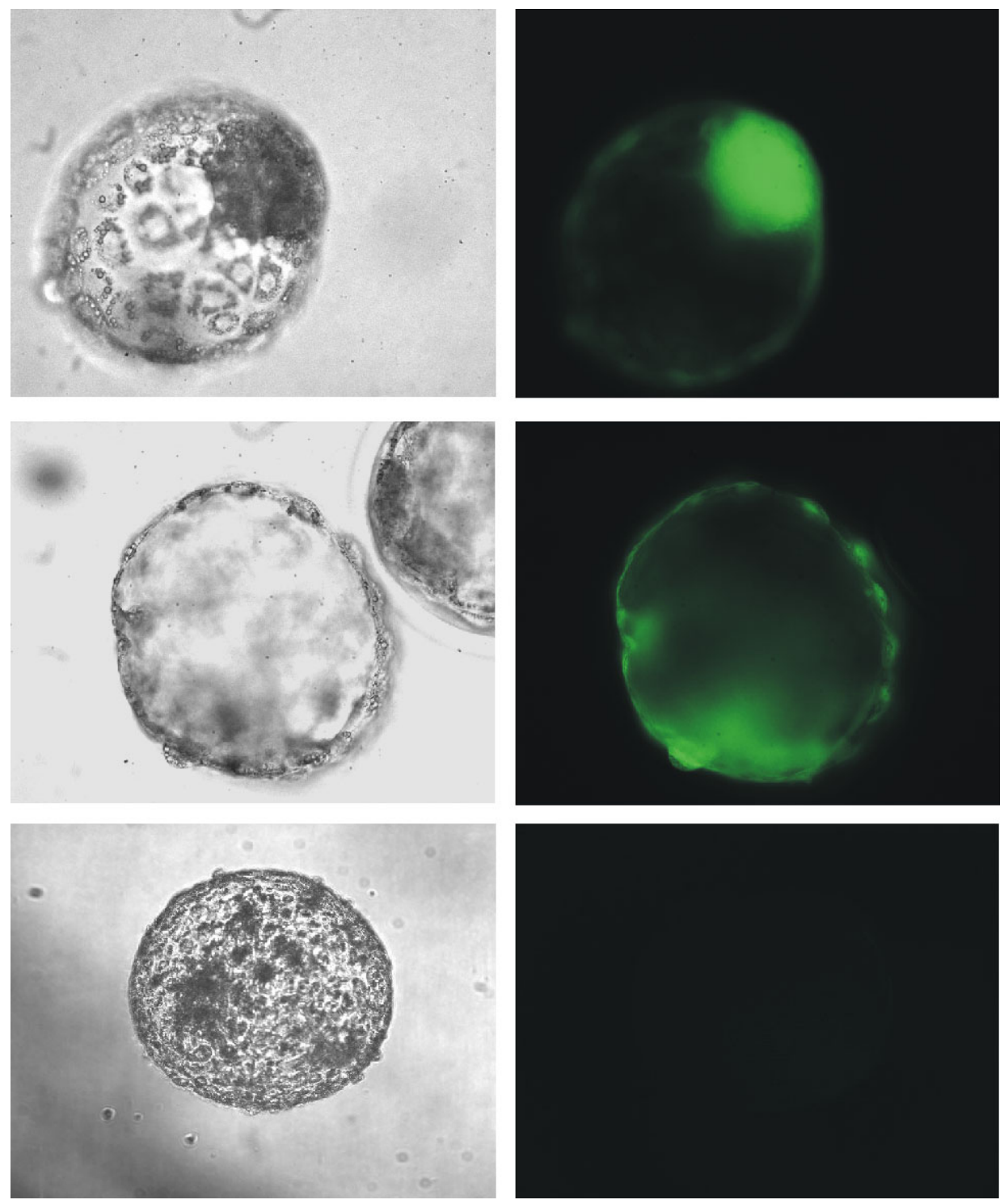


\subsection{Effect of microdrilling of oocytes on polyspermy}

Pronuclear formation in zygotes, obtained from MD oocytes, was analyzed by orcein staining. Fertilization rates were $83 \%$ (26/31) after incubation with $10^{6}$ spermatozoa/ml for $18 \mathrm{~h}$ and $87 \%$ (20/23) when $0.5 \times 10^{6}$ spermatozoa/ml were added for $8 \mathrm{~h}$. The corresponding polyspermy rates were 38\% (10/26) and 40\% (8/20), respectively. After further reduction of coincubation time to $4 \mathrm{~h}$, no fertilization was observed. A control group of zygotes $(n=20)$ originating from denuded fertilized oocytes with an intact ZP did not show signs of polyspermy. Fig. 10 shows a normally fertilized zygote with two pronuclei (left) and a polysperm zygote with three pronuclei (right).

Fig 10 pronuclear formation in bovine zygotes; normally fertilized zygote (left), polysperm zygote (right)
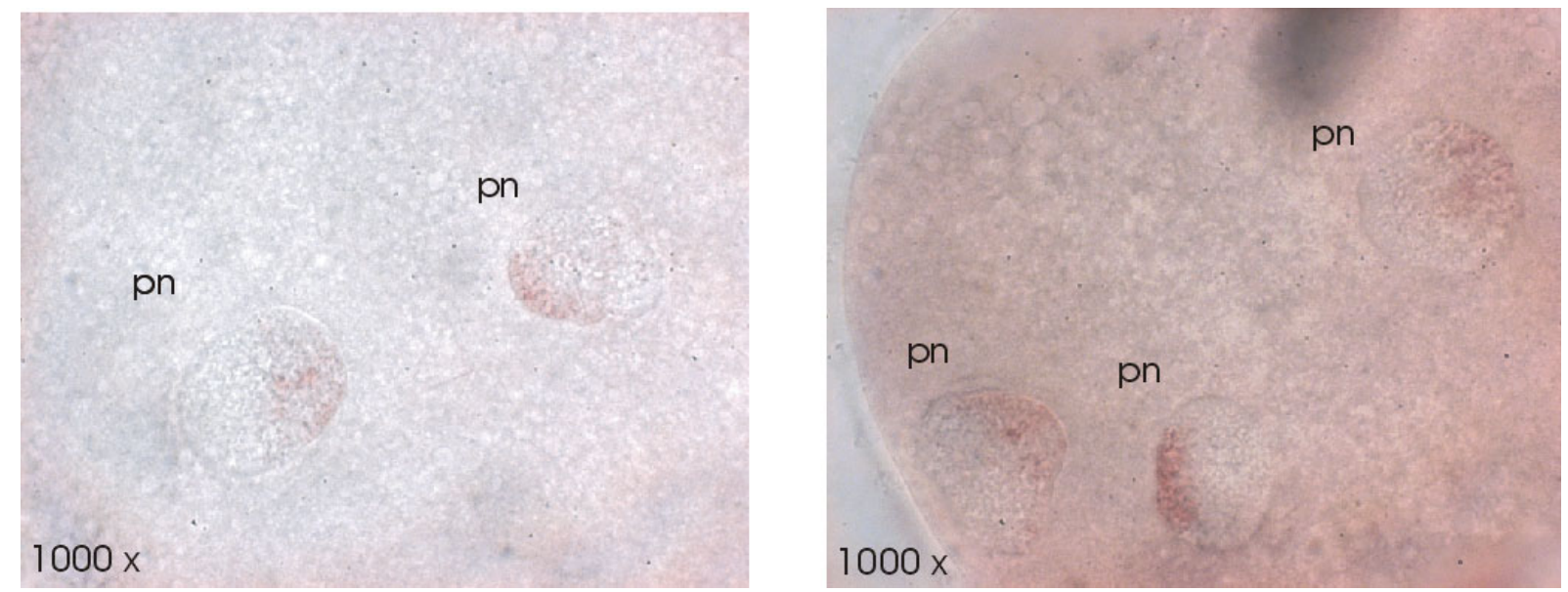
Table 4 Effects of developmental stage, treatment, virus and the interactions between these factors on embryonic development and transgene expression

\begin{tabular}{lllll}
\hline Model & $\begin{array}{l}\text { Cleavage } \\
\text { rate }\end{array}$ & $\begin{array}{l}\text { Blastocyst } \\
\text { rate }\end{array}$ & $\begin{array}{l}\text { Expression } \\
\text { rate }\end{array}$ & $\begin{array}{l}\text { Overall } \\
\text { Efficiency }\end{array}$ \\
\hline Stage & $5.95^{*}$ & $18.53^{* *}$ & $5.53^{*}$ & 0.88 \\
Treatment & 0.98 & $25.26^{\star * *}$ & 0.88 & $7.1^{*}$ \\
Virus & 0.00 & 0.03 & $43,4^{* * *}$ & $48.36^{* * *}$ \\
Treatment $x$ Virus & 0.02 & 0.28 & 0.88 & $7.1^{*}$ \\
Stage $x$ Virus & 0.50 & 0.27 & $5.53^{*}$ & 0.88 \\
\hline
\end{tabular}

The table shows F-values and levels of significance $\left({ }^{*} p<0.05\right.$; ${ }^{* *} p<0.01$; ${ }^{* * *} p<$ 0.001 ). All possible interactions between stage, treatment and virus were initially included in the model, but were removed from the final model if they had no significant effect 
Table 5 Embryonic development and transduction efficacies

\begin{tabular}{|c|c|c|c|c|c|c|}
\hline Stage & Treatment & $\begin{array}{c}\text { Group size } \\
n\end{array}$ & $\begin{array}{c}\text { Cleavage } \\
\text { rate } \\
{[\%]}\end{array}$ & $\begin{array}{c}\text { Blastocyst } \\
\text { rate }^{1} \\
{[\%]}\end{array}$ & $\begin{array}{c}\text { Expression } \\
\text { rate }^{2} \\
{[\%]}\end{array}$ & $\begin{array}{c}\text { Overall } \\
\text { efficacy }^{3} \\
{[\%]}\end{array}$ \\
\hline Oocyte & MD & 126 & $73.8 \pm 5.8^{\mathrm{ab}}$ & $14.4 \pm 6.9^{c}$ & $44.0 \pm 9.2^{\mathrm{fg}}$ & $6.9 \pm 2.3^{h}$ \\
\hline Oocyte & Sham-MD & 184 & $67.3 \pm 4.9^{\mathrm{a}}$ & $12.7 \pm 6.0^{c}$ & & \\
\hline Oocyte & MI & 248 & $74.8 \pm 4.9^{\mathrm{ab}}$ & $34.5 \pm 6.0^{d}$ & $67.3 \pm 8.0^{f}$ & $17.6 \pm 2.0^{i}$ \\
\hline Oocyte & Sham-MI & 89 & $75.8 \pm 5.8^{\mathrm{ab}}$ & $39.3 \pm 6.9^{\mathrm{de}}$ & & \\
\hline Zygote & $M D$ & 218 & $77.7 \pm 4.9^{\mathrm{ab}}$ & $36.0 \pm 6.0^{d}$ & $26.3 \pm 8.0^{g}$ & $6.4 \pm 2.0^{h}$ \\
\hline Zygote & Sham-MD & 99 & $85.2 \pm 5.8^{b}$ & $31.1 \pm 6.9^{\mathrm{cd}}$ & & \\
\hline Zygote & MI & 182 & $84.3 \pm 5.8^{b}$ & $57.9 \pm 6.9^{\mathrm{e}}$ & $26.4 \pm 9.2^{\mathrm{g}}$ & $12.3 \pm 2.3^{\mathrm{hi}}$ \\
\hline Zygote & Sham-MI & 56 & $82.2 \pm 5.8^{\mathrm{ab}}$ & $56.4 \pm 6.9^{\mathrm{e}}$ & & \\
\hline
\end{tabular}

The table shows the group sizes, the means and the standard error (SEM) of the developmental parameters. Group size results of at least three independent experiments. ${ }^{1}$ Blastocyst rate was calculated based on the number of cleaved embryos, ${ }^{2}$ expression rate is based on the total number of blastocysts. ${ }^{3}$ Overall efficacy is the proportion of eGFP-positive blastocysts relative to the number of oocytes or zygotes used. Within each column, proportions with different superscripts differ significantly $(p<0.05)$. 


\section{Discussion}

This study evaluated the efficacy of a new route of lentiviral gene transfer: MD of oocytes or zygotes and subsequent incubation in virus suspension. Transduction experiments were performed both on bovine zygotes and oocytes, because a pilot study demonstrated that the use of oocytes resulted in a higher yield of eGFP expressing blastocysts after subzonal injection of the same lentiviral vector (Hofmann et al., 2003).

In our experiments the removal of cumulus cells was essential to visualize the ZP for micromanipulation. This causes a substantial decrease in sperm penetration rates in zona-intact oocytes (Tanghe et al., 2003), which may explain the lower rates of development after subzonal virus injection of oocytes as compared to zygotes. Cumulus cells are known to secrete a complex mixture of substances required for fertilization, since a cumulus cell-conditioned medium as well as a cumulus cell monolayer improved fertilization rates of denuded oocytes in comparison to cumulus free fertilization (Tanghe et al., 2003).

Due to the experimental requirements of this study, the start of fertilization was different between the oocyte and zygote treatment groups: $24-25 \mathrm{~h}$ and $19-20 \mathrm{~h}$ after onset of oocyte maturation, respectively. Previous studies demonstrated that within a period of $21-24 \mathrm{~h}$ after the onset of maturation, the start of fertilization does not influence development to blastocyst (Iwata et al., 2004). Thus, it is unlikely that delayed fertilization was the reason for lower blastocyst rates in the oocyte treatment groups.

For MD oocytes, the high degree of polyspermy is most likely responsible for the reduced blastocyst rate, because polyploid bovine embryos do not develop to blastocysts (Hyttel et al., 2001). In mice, embryonic development was not hampered by a hole in the ZP and polyploidy was observed only occasionally (Germond et al., 1996). Instead, fertilization rates of microdrilled mouse oocytes and implantation rates of the resulting embryos were improved (Germond et al., 1996). Different hole diameters, which are necessary for complete hatching of blastocysts in mouse (5 to $10 \mu \mathrm{m}$; Germond et al., 1996) and bovine (40 $\mu \mathrm{m}$; Schmoll et al., 2003), could be a reason for the high proportion of polyspermy in our study.

The reduced blastocyst rate after MD of bovine oocytes and zygotes as compared to the corresponding $\mathrm{Ml}$ groups might be a specific consequence of laser treatment in 
this species. A hole in the ZP did per se not hamper development of bovine embryos, since mechanical slicing of the ZP at the zygote stage did not decrease development to blastocyst as compared to non-sliced control zygotes. Laser beam is known to cause a disruption of the ZP due to a highly localized photo thermolysis of the protein matrix (Rink et al., 1996). Previous studies on MD in mouse reported no adverse effects on embryonic development (Germond et al., 1995). We can currently not explain why development of bovine oocytes and zygotes appears to be negatively affected by laser MD.

The rate of eGFP expressing bovine blastocysts was higher when oocytes were infected with the lentiviral vector, irrespective of the route of infection (subzonal injection or ZP microdrilling). This finding is in line with results of a previous study, in which bovine oocytes and zygotes were infected with vectors derived from prototypic retroviruses (Moloney murine leukemia virus) by subzonal injection (Chan et al., 1998). The authors concluded that germinal vesicle breakdown together with arrest of the oocyte in metaphase II prolongs exposure time of metaphase chromosomes to the virus. In contrast to prototypic retroviruses, lentiviruses are able to pass through the nuclear membrane due to a central DNA flap (Zennou et al., 2000). Nevertheless, virus integration might be more efficient without this barrier at the oocyte stage.

In our study, we monitored successful lentiviral transduction of oocytes or zygotes by the presence of green fluorescence at the blastocyst stage. We have previously shown that, after lentiviral transduction of oocytes, all resulting eGFP expressing blastocysts, which were transferred to recipients and developed to term, gave rise to transgenic calves exhibiting a stable long-term eGFP expression (Hofmann et al., 2004). Thus eGFP expression at the blastocyst stage is a clear indicator of lentiviral integration. In fact, this readout may even underestimate the rate of lentiviral transduction, because - in contrast to prior assumptions - we recently found that a subset of lentiviral integrants may be silenced by DNA hypermethylation (Hofmann et al., 2006).

In summary, our study demonstrates the feasibility of laser-assisted lentiviral gene transfer into bovine oocytes and zygotes. However, further optimization of the procedure is required, mainly to reduce the incidence of polyspermy after ZP microdrilling of oocytes and to eliminate negative effects on embryonic development as observed in the present study. 


\section{Future Prospects}

Although the limitations of transgenic livestock technology, such as high costs and rather insufficient methods could not be overcome sufficiently, a slow but steady progress can be observed during the last 25 years.

Improvement of in vitro production techniques of bovine embryos faciliates the application of this technique to address fundamental questions of the endocrine control, the molecular switches and the metabolic pathways that regulate early embryonic development (Galli et al., 2003). Therefore numerous reports exist, where this research tool is used to obtain information about transgenesis, gene targeting and NT in bovine in vitro (Iguma et al., 2005, Cho et al., 2004, Arat et al., 2002, Wells and Powell, 2000, Rosochacki et al., 2003).

The use of transgenic cattle for agricultural purposes was much discussed, but practical application of transgenic technology was restricted to plants (Maga, 2005). Many proof-of-principle studies have been carried out, but the commercial application of this technology is still not existent (Clark and Whitelaw, 2003). The first report, in which it was demonstrated that genetic engineering of livestock might benefit animal agriculture, was done by Wall, et al. (2005). They produced transgenic Jersey cattle via NT, which expressed lysostaphin in their milk to gain resistance against Staphylococcus aureus infection of the mammary gland. To increase public acceptance for genetically modified products from animals, inducible vector systems were proposed, which could contribute to dispel doubts regarding the safety of products from the lysostaphin transgenic cows (Rainard, 2005).

The creation of BSE resistant cattle is one more approach to introduce transgenic animal technology in agriculture as well as in biomedicine. The idea was to eliminate the risk of transmission of the disease to humans from animal products, such as milk, meat or proteins produced from transgenic cows. Inactivation of the PRNP-gene can be done via gene targeting in cultured bovine somatic cells with subsequent NT into enucleated oocytes. PRNP-gene deficient cattle are supposed to be resistant against BSE, because it could be shown that PRNP-gene deficient mice could not be infected with scrapie-protein. Mice carrying only one active allele of the PRNP gene showed a prolonged incubation time after infection, which indicated a gene-doseeffect (Bueler et al., 1993). 
Another promising tool for making transgenic livestock more feasible is lentiviral gene transfer, although until now only proof-of-principle studies with a reporter gene exist (Hofmann et al., 2003, Hofmann et al., 2004). Though lentiviral vectors are introduced into the germ-line and therefore bequeathed to the offspring, low or undetectable levels of expression in one-third of the proviral integrants was found. A inverse correlation between proviral methylation and expression level was reported, which indicated that DNA hypermethylation plays a major role in lentivirus silencing in transgenic animals (Hofmann et al., 2006).

Another interesting and rather novel approach to exert influence on gene expression in animals are lentiviral vectors carrying siRNAs, which cause via RNA interference a knock down of genes. RNA interference (RNAi) represents an evolutionarily conserved cellular defense for controlling the expression of foreign genes in most eukaryotic cells. RNAi is triggered by double-stranded RNA (dsRNA) and causes sequence-specific mRNA degradation of single-stranded target RNAs homologous in response to dsRNA. The mediators of mRNA degradation are small interfering RNA duplexes (siRNAs), which are produced from long dsRNA by enzymatic cleavage in the cell. siRNAs are approximately twenty-one nucleotides in length, and have a base-paired structure characterized by two-nucleotide 3 '-overhangs (Tuschl and Borkhardt, 2002).

When zygotes of GFP-transgenic mice were infected with a lentiviral vector carrying a siRNA against GFP, the fluorescence of the resulting blastocysts was reduced. Furthermore pubs from F1 progeny, which expressed eGFP, showed diminished fluorescence and decreased GFP (Tiscornia et al., 2003, Rubinson et al., 2003). This technology might be an alternative approach to NT for gene knock out in farm animals and for studying gene function. It can be done in vitro as well as in vivo. Developmental capacity of embryos infected with lentiviral vectors is not hampered by the procedure and developmental abnormalities in resulting offspring might not occur (Pfeifer, 2004). Furthermore it might be used to suppress infectious pathogens, particularly viruses, by targeting the RNA of the invading agent (Clark and Whitelaw, 2003)

Until today ES cells are only available form mice. The advantages of pluripotent ES cells from farm animals as donor nuclei for nuclear transfer are evident, since mouse blastocysts from embryos reconstructed by nuclear transfer with nuclei from ES cells lead to a $10-20$ fold higher efficiency than blastocysts reconstructed by SCNT with 
cumulus cells. This indicates that ES cells are easier to reprogram (Gjorret and Maddox-Hyttel, 2005). Moreover, precise genetic modifications by homologous recombination occur at a rate of approximately two orders of magnitude higher in ES cells than in somatic cells (Piedrahita, 2000) and their extended in vitro live span allows for genetic manipulation (Gjorret and Maddox-Hyttel, 2005). Attempts to establish routine procedures of the monitoring of key functional ES cell parameters include determination of pluripotency markers, such as Oct 4 or Nanog, assessment of telomerase activity and cell and colony morphology (Gjorret and Maddox-Hyttel, 2005). But so far no ES cell like cultures from other mammal animal than mouse could be established, which showed the characteristic parameters of immortality, pluripotency and propensity to targeted mutations by homologous recombination, combined with their capability for germ line transmission (Capecchi, 1989).

Routine application of $1.48 \mu \mathrm{m}$ wavelength laser technology in human assisted reproduction has shown to fulfill safety requirements (Germond, Nocera, et al. 1995 ) for performing ICSI, polar body biopsy or assisted hatching (Ebner, Moser, et al. 2005). Comparative studies found no adverse effect of the laser drilling procedure on the developmental capacity of human embryos (Chatzimeletiou, Morrison, et al. ) but report an improvement of blastocyst formation (Tinney, Windt, et al. 2005) or implantation rates (Germond, Nocera, et al. 1996) in mice. However, the use of laser technology is rather cost-intensive and therefore only reasonable in animal embryo technologies when single embryos are of high value. This might be the case when a specific oocyte or embryo donor is used, for example in OPU programs in cattle, since a microdrilled opening in the ZP of IVP bovine embryos faciliates hatching of blastocysts (Schmoll, Schneider, et al. 2003).

The constant search for new routes of gene transfer, the discovery of genetic mechanisms, which can be used for transgenic technology (RNAi) and the ongoing improvement of in vitro techniques provide for a slow but steady advance in the feasibility of large animal transgenesis. 


\section{Summary}

Lentiviral transduction of oocytes or early embryos is an efficient strategy to generate transgenic rodents and livestock. We evaluated laser-based microdrilling (MD) of the zona pellucida, which is a physical barrier for viral infection, and subsequent incubation in virus suspension as a new route for lentiviral transgenesis in bovine. Lentiviral vectors carrying an eGFP expression cassette were used to transduce oocytes or zygotes after MD as compared to the established subzonal virus injection technique (MI). The type of manipulation (MD vs. MI) did not affect cleavage rates, but had a significant effect on blastocyst rates $(p<0.001)$. Ml of virus or sham-MI (buffer) resulted in higher blastocyst rates as compared to MD, both in the oocyte and zygote treatment groups. The latter exhibited higher rates of early cleavage $(p<$ $0.05)$ and blastocyst rates $(p<0.01)$. The proportion of eGFP expressing blastocysts was higher after infection of oocytes (MD: $44 \pm 9 \%$; Ml: $67 \pm 8 \%$ ) than after infection of zygotes (MD: $26 \pm 8 \%$; MI: $26 \pm 9 \%$ ). Overall efficacy (eGFP-positive blastocysts per treated oocytes or zygotes) was highest after $\mathrm{Ml}$ of oocytes $(18 \pm 2 \%)$. Our study demonstrates the feasibility of laser-assisted lentiviral gene transfer into bovine oocytes and zygotes. However, further optimization of the procedure is required, mainly to reduce the incidence of polyspermy after MD of oocytes and to eliminate negative effects of MD on early embryonic development. 


\section{Zusammenfassung}

Laser-unterstützter Lentiviraler Gentransfer zur Erzeugung transgener Rinder Lentiviraler Gentransfer in Eizellen oder präimplantive Embryonen ist eine effiziente Strategie zur Erstellung transgener Nager oder Nutztiere. Die Zona pellucida stellt eine physikalische Barriere gegen virale Infektionen dar. Im Rahmen unserer Untersuchung wurde geprüft, ob das Lochen der ZP mit einem Laser, mit darauf folgender Inkubation der Eizellen oder Zygoten in Virus-Suspension geeignet ist, transgene Rinderembryonen zu erzeugen. Sowohl Oozyten wie auch Zygoten wurden mit dem Laser gelocht (MD) und auch subzonal mikroinjiziert (MI). Der verwendete Vektor enthielt eine eGFP Expressionskassette unter der Kontrolle des pgk Promotors. Die Art der Behandlung (MD versus MI) hatte keinen Effekt auf die Teilungsraten, aber einen signifikanten Einfluss auf die Blastocystenraten ( $p<$ 0,001). Sowohl in den Eizell- als auch in den Zygotengruppen resultierte MI des Virus oder der Pufferlösung in höheren Blastozystenraten als in den gelochten Gruppen. In den Zygotengruppen konnten höhere Teilungsraten $(p<0,5)$ und höhere Blastozystenraten $(p<0,01)$ beobachtet werden. Der Anteil eGFP exprimierender Blastozysten war nach der Infektion von Eizellen (MD: $44 \pm 9 \%$; MI: 67士8\%) höher als nach der Infektion von Zygoten (MD: $26 \pm 8 \%$; MI: $26 \pm 9 \%$ ). Die Gesamtausbeute an exprimierenden Blastozysten (eGFP positive Blastozysten pro behandelter Eizelle oder Zygote) war nach der MI von Eizellen am höchsten (18 \pm 2\%). Unsere Untersuchung zeigt, dass Laser-unterstützter lentiviraler Gentransfer in bovine Eizellen und Zygoten möglich ist. Jedoch sind weitere Verbesserungen des Protokolls nötig, um das Auftreten von Polyspermie und die negativen Effekte der Laserbehandlung auf die Entwicklungskapazität von präimplantiven Embryonen zu reduzieren. 


\section{Publications}

This study is accepted for publication in Transgenic Research.

Within this project "Lentiviral Transgenesis in farm animals" two more publications were produced:

1. Hofmann A, Kessler B, Ewerling S, Weppert M, Vogg B, Ludwig H, Stojkovic, M., Boelhauve M, Brem G, Wolf E, Pfeifer A, 2003:

Efficient transgenesis in farm animals by lentiviral vectors. EMBO Rep. 4 10541060.

2. Hofmann A, Kessler B, Ewerling S, Kabermann A, Brem G, Wolf E, Pfeifer A, 2006:

Epigenetic regulation of lentiviral transgene vectors in a large animal model. Mol.Ther. 13 59-66. 


\section{References}

Antinori,S., Versaci,C., Fuhrberg,P., Panci,C., Caffa,B., and Gholami,G.H. (1994).

Seventeen live births after the use of an erbium-yytrium aluminum garnet laser in the treatment of male factor infertility. Hum. Reprod. 9, 1891-1896.

Araki, N. Relationships Among Follicular Fluid Estradiol-17ß Concentration, Morphology of Cumulus-Oocyte Complex and Developmental Capacity of Individually Matured, Fertilized and Cultured Bovine Oocytes In Vitro. SATO, K HAYASHI Miymaoto Yutaka F. Journal of Reproduction and Development 45, 359-165. 1998. Ref Type: Generic

Arat,S., Gibbons,J., Rzucidlo,S.J., Respess,D.S., Tumlin,M., and Stice,S.L. (2002). In vitro development of bovine nuclear transfer embryos from transgenic clonal lines of adult and fetal fibroblast cells of the same genotype. Biol. Reprod. 66, 1768-1774.

Arlotto,T., Schwartz,J.L., First,N.L., and Leibfried-Rutledge,M.L. (1996). Aspects of follicle and oocyte stage that affect in vitro maturation and development of bovine oocytes. Theriogenology 45, 943-956.

Austin,C.R. (1951). Observations on the penetration of the sperm in the mammalian egg. Aust. J. Sci. Res. (B) 4, 581-596.

Bavister,B.D. (2000). Interactions Between Embryos and the Culture Milieu. Theriogenology 53, 619-626.

Bordignon,V., Keyston,R., Lazaris,A., Bilodeau,A.S., Pontes,J.H., Arnold,D., Fecteau,G., Keefer,C., and Smith,L.C. (2003). Transgene expression of green fluorescent protein and germ line transmission in cloned calves derived from in vitrotransfected somatic cells. Biol. Reprod. 68, 2013-2023.

Bowen,R.A., Reed,M., Schnieke,A., Seidel,J., Brink,Z., and Stacey,A. (1993).

Production of transgenic cattle from PCR-screened embryos. Theriogenology 39 , 194. 
Brem,G.; Besenfelder,U.; Aigner,B.; Muller,M.; Liebl,I.; Schutz,G.; Montoliu,L. (1996) YAC transgenesis in farm animals: rescue of albinism in rabbits. Mol. Reprod. Dev. 1, $56-62$.

Brem, G. Transgenic Animals. Biotechnology 2, 746-832. 1993.

Brem,G., Brening,B., Goodman,H.M., Selden,R.C., Graf,F., Kruff,B., Springmann,K., Hondele,J., Meyer,J., Winnacker,E.-L. (1985). Production of transgenic mice, rabbits and pigs by microinjection into pronuclei. Zuchthygiene 20, 251-252.

Brophy,B., Smolenski,G., Wheeler,T., Wells,D., L'Huillier,P., and Laible,G. (2003). Cloned transgenic cattle produce milk with higher levels of beta-casein and kappacasein. Nat. Biotechnol. 21, 157-162.

Bueler,H., Aguzzi,A., Sailer,A., Greiner,R.A., Autenried,P., Aguet,M., and Weissmann,C. (1993). Mice devoid of PrP are resistant to scrapie. Cell 73, 13391347.

Capecchi,M.R. (1989). Altering the genome by homologous recombination. Science 244, 1288-1292.

Cetica,P.D., Dalvit,G.C., and Beconi,M.T. (1999). Study of evaluation criteria used for in vitro bovine oocyte selection and maturation. Biocell 23, 125-133.

Chan,A.W. (1999). Transgenic animals: current and alternative strategies. Cloning 1, 25-46.

Chan,A.W., Homan,E.J., Ballou,L.U., Burns,J.C., and Bremel,R.D. (1998b). Transgenic cattle produced by reverse-transcribed gene transfer in oocytes. Proc. Natl. Acad. Sci. U. S. A 95, 14028-14033.

CHANG,M.C. (1951). Fertilizing capacity of spermatozoa deposited into the fallopian tubes. Nature 168, 697-698.

Chatzimeletiou,K.; Morrison,E.E.; Panagiotidis,Y.; Prapas,N.; Prapas,Y.;

Rutherford,A.J.; Grudzinskas,G.; Handyside,A.H. (2005). Comparison of effects of zona drilling by non-contact infrared laser or acid Tyrode's on the development of human biopsied embryos as revealed by blastomere viability, cytoskeletal analysis and molecular cytogenetics. Reprod. Biomed. Online 11, 697 - 710 
Chen,S.H., Vaught,T.D., Monahan,J.A., Boone,J., Emslie,E., Jobst,P.M., Lamborn,A.E., Schnieke,A., Robertson,L., Colman,A., Dai,Y., Polejaeva,I.A., and Ayares,D.L. (2002). Efficient production of transgenic cloned calves using preimplantation screening. Biol. Reprod. 67, 1488-1492.

Cho,J., Bhuiyan,M.M., Shin,S., Park,E., Jang,G., Kang,S., Lee,B., and Hwang,W. (2004). Development potential of transgenic somatic cell nuclear transfer embryos according to various factors of donor cell. J. Vet. Med. Sci. 66, 1567-1573.

Cibelli,J.B., Stice,S.L., Golueke,P.J., Kane,J.J., Jerry,J., Blackwell,C., Ponce de Leon,F.A., and Robl,J.M. (1998). Cloned transgenic calves produced from nonquiescent fetal fibroblasts. Science 280, 1256-1258.

Clark,A.J. (1998). The mammary gland as a bioreactor: expression, processing, and production of recombinant proteins. J. Mammary. Gland. Biol. Neoplasia. 3, 337-350.

Clark,J. and Whitelaw,B. (2003). A future for transgenic livestock. Nat. Rev. Genet. 4, 825-833.

Colman,A. (1996). Production of proteins in the milk of transgenic livestock: problems, solutions, and successes. Am. J. Clin. Nutr. 63, 639S-645S.

Coulibaly,S., Besenfelder,U., Miller,I., Zinovieva,N., Lassnig,C., Kotler,T., Jameson,J.L., Gemeiner,M., Muller,M., and Brem,G. (2002). Expression and characterization of functional recombinant bovine follicle-stimulating hormone (boFSHalpha/beta) produced in the milk of transgenic rabbits. Mol. Reprod. Dev. 63, 300-308.

Cox,J.F., Hormazabal,J., and Santa Maria,A. (1993). Effect of the cumulus on in vitro fertilization of bovine matured oocytes. Theriogenology 40, 1259-1267.

De Vos,A. and Van Steirteghem,A. (2000). Zona hardening, zona drilling and assisted hatching: new achievements in assisted reproduction. Cells Tissues. Organs 166, 220-227.

de Wit,A.A. and Kruip,T.A. (2001). Bovine cumulus-oocyte-complex-quality is reflected in sensitivity for alpha-amanitin, oocyte-diameter and developmental capacity. Anim Reprod. Sci. 65, 51-65. 
Denning,C. and Priddle,H. (2003). New frontiers in gene targeting and cloning: success, application and challenges in domestic animals and human embryonic stem cells. Reproduction 126, 1-11.

Donovan,D.M., Kerr,D.E., and Wall,R.J. (2005). Engineering disease resistant cattle. Transgenic Res. 14, 563-567.

Duchler,M., Pengg,M., Schuller,S., Pfneisl,F., Bugingo,C., Brem,G., Wagner,E., Schellander,K., and Muller,M. (2002). Somatic gene transfer into the lactating ovine mammary gland. J. Gene Med. 4, 282-291.

Ebner,T., Moser,M., and Tews,G. (2005). Possible applications of a non-contact 1.48 microm wavelength diode laser in assisted reproduction technologies. Hum. Reprod. Update. 11, 425-435.

el Danasouri,I., Westphal,L.M., Neev,Y., Gebhardt,J., Louie,D., and Berns,M.W. (1993). Zona opening with $308 \mathrm{~nm} \mathrm{XeCl} \mathrm{excimer} \mathrm{laser} \mathrm{improves} \mathrm{fertilization} \mathrm{by}$ spermatozoa from long-term vasectomized mice. Hum. Reprod. 8, 464-466.

Evans,M.J. and Kaufman,M.H. (1981). Establishment in culture of pluripotential cells from mouse embryos. Nature 292, 154-156.

Eyestone,W.H. (1994). Challenges and progress in the production of transgenic cattle. Reprod. Fertil. Dev. 6, 647-652.

Eyestone,W.H. (1999). Production and breeding of transgenic cattle using in vitro embryo production technology. Theriogenology 51, 509-517.

Eyestone,W.H. and First,N.L. (1989). Co-culture of early cattle embryos to the blastocyst stage with oviducal tissue or in conditioned medium. J. Reprod. Fertil. 85, 715-720.

Eyestone,W.H., Gowallis,M., Monohan,J., Sink,T., Ball,S.F., and Cooper,J.D. (1998). Production of transgenic cattle expressing human [alpha]-lactalbumin in milk. Theriogenology 49, 386.

Eyestone,W.H., Krisher,R.L., and Gibbons,J. (1995). Early fetal development and transgene integration after pronuclear injection and transfer of multiple embryos to recipient cattle. Theriogenology 43, 208. 
Eyestone,W.H., Vignieri,J., and First,N.L. (1987). Co-culture of early bovine embryos with oviductal epithelium. Theriogenology 27, 228.

Ferreira,T.B., Alves,P.M., Aunins,J.G., and Carrondo,M.J. (2005). Use of adenoviral vectors as veterinary vaccines. Gene Ther. 12 Suppl 1, S73-S83.

Follenzi,A., Ailles,L.E., Bakovic,S., Geuna,M., and Naldini,L. (2000). Gene transfer by lentiviral vectors is limited by nuclear translocation and rescued by HIV-1 pol sequences. Nat. Genet. 25, 217-222.

Fry,R.C., Niall,E.M., Simpson,T.L., Squires,T.J., and Reynolds,J. (1997). The collection of oocytes from bovine ovaries. Theriogenology 47, 977-987.

Galli,C., Duchi,R., Crotti,G., Turini,P., Ponderato,N., Colleoni,S., Lagutina,I., and Lazzari,G. (2003). Bovine embryo technologies. Theriogenology 59, 599-616.

Gallo,P., Dharmapuri,S., Cipriani,B., and Monaci,P. (2005). Adenovirus as vehicle for anticancer genetic immunotherapy. Gene Ther. 12 Suppl 1, S84-S91.

Germond,M., Nocera,D., Senn,A., Rink,K., Delacretaz,G., and Fakan,S. (1995a). Microdissection of mouse and human zona pellucida using a 1.48-microns diode laser beam: efficacy and safety of the procedure. Fertil. Steril. 64, 604-611.

Germond,M., Nocera,D., Senn,A., Rink,K., Delacretaz,G., Pedrazzini,T., and Hornung,J.P. (1996). Improved fertilization and implantation rates after non-touch zona pellucida microdrilling of mouse oocytes with a 1.48 microm diode laser beam. Hum. Reprod. 11, 1043-1048.

Gilchrist,R.B., Ritter,L.J., and Armstrong,D.T. (2004). Oocyte-somatic cell interactions during follicle development in mammals. Anim Reprod. Sci. 82-83, 431-446.

Gjorret,J.O. and Maddox-Hyttel,P. (2005). Attempts towards derivation and establishment of bovine embryonic stem cell-like cultures. Reprod. Fertil. Dev. 17, 113-124.

Golovan,S.P., Meidinger,R.G., Ajakaiye,A., Cottrill,M., Wiederkehr,M.Z., Barney,D.J., Plante,C., Pollard,J.W., Fan,M.Z., Hayes,M.A., Laursen,J., Hjorth,J.P., Hacker,R.R., Phillips,J.P., and Forsberg,C.W. (2001). Pigs expressing salivary phytase produce low-phosphorus manure. Nat. Biotechnol. 19, 741-745. 
Gong,G., Dai,Y., Fan,B., Zhu,H., Zhu,S., Wang,H., Wang,L., Tang,B., Li,R., Wan,R., Liu,Y., Huang,Y., Zhang,L., Sun,X., and Li,N. (2004). Birth of calves expressing the enhanced green fluorescent protein after transfer of fresh or vitrified/thawed blastocysts produced by somatic cell nuclear transfer. Mol. Reprod. Dev. 69, 278288.

Gordo,A.C., He,C.L., Smith,S., and Fissore,R.A. (2001). Mitogen activated protein kinase plays a significant role in metaphase II arrest, spindle morphology, and maintenance of maturation promoting factor activity in bovine oocytes. Mol. Reprod. Dev. 59, 106-114.

Gordon, I. Laboratory Production of Cattle Embryos. 2003. CABI publishing.

Gordon,J.W. and Ruddle,F.H. (1981). Integration and stable germ line transmission of genes injected into mouse pronuclei. Science 214, 1244-1246.

Gorus,F.K. and Pipeleers,D.G. (1981). A rapid method for the fractionation of human spermatozoa according to their progressive motility. Fertil. Steril. 35, 662-665.

Gossler,A., Doetschman,T., Korn,R., Serfling,E., and Kemler,R. (1986).

Transgenesis by means of blastocyst-derived embryonic stem cell lines. Proc. Natl. Acad. Sci. U. S. A 83, 9065-9069.

Green,D.P. (1997). Three-dimensional structure of the zona pellucida. Rev. Reprod. $2,147-156$.

Grosse-Hovest,L., Muller,S., Minoia,R., Wolf,E., Zakhartchenko,V., Wenigerkind,H., Lassnig,C., Besenfelder,U., Muller,M., Lytton,S.D., Jung,G., and Brem,G. (2004). Cloned transgenic farm animals produce a bispecific antibody for $\mathrm{T}$ cell-mediated tumor cell killing. Proc. Natl. Acad. Sci. U. S. A 101, 6858-6863.

Hammer,R.E., Pursel,V.G., Rexroad,C.E., Jr., Wall,R.J., Bolt,D.J., Ebert,K.M., Palmiter,R.D., and Brinster,R.L. (1985). Production of transgenic rabbits, sheep and pigs by microinjection 100. Nature $315,680-683$. 
Han,Z.M., Chen,D.Y., Li,J.S., Sun,Q.Y., Wan,Q.H., Kou,Z.H., Rao,G., Lei,L., Liu,Z.H., and Fang,S.G. (2004). Mitochondrial DNA heteroplasmy in calves cloned by using adult somatic cell. Mol. Reprod. Dev. 67, 207-214.

Hart,S.L. (2003). Large animal models: bridging the gap. Mol. Ther. 8, 528-529. Haskell,R.E. and Bowen,R.A. (1995). Efficient production of transgenic cattle by retroviral infection of early embryos. Mol. Reprod. Dev. 40, 386-390.

Haskins,M., Casal,M., Ellinwood,N.M., Melniczek,J., Mazrier,H., and Giger,U. (2002). Animal models for mucopolysaccharidoses and their clinical relevance. Acta Paediatr. Suppl 91, 88-97.

Hazeleger,N.L., Hill,D.J., Stubbing,R.B., and Walton,J.S. (1995). Relationship of morphology and follicular fluid environment of bovine oocytes to their developmental potential in vitro. Theriogenology 43, 509-522.

He,C.L., Damiani,P., Parys,J.B., and Fissore,R.A. (1997). Calcium, calcium release receptors, and meiotic resumption in bovine oocytes. Biol. Reprod. 57, 1245-1255.

Herrler,A. and Beier,H.M. (2000). Early embryonic coats: morphology, function, practical applications. An overview. Cells Tissues. Organs 166, 233-246.

Heyman,Y. (2005). Nuclear transfer: a new tool for reproductive biotechnology in cattle. Reprod. Nutr. Dev. 45, 353-361.

Hiendleder,S., Zakhartchenko,V., Wenigerkind,H., Reichenbach,H.D., Bruggerhoff,K., Prelle,K., Brem,G., Stojkovic,M., and Wolf,E. (2003). Heteroplasmy in bovine fetuses produced by intra- and inter-subspecific somatic cell nuclear transfer: neutral segregation of nuclear donor mitochondrial DNA in various tissues and evidence for recipient cow mitochondria in fetal blood. Biol. Reprod. 68, 159-166.

Hill,J.R., Winger,Q.A., Long,C.R., Looney,C.R., Thompson,J.A., and Westhusin,M.E. (2000). Development rates of male bovine nuclear transfer embryos derived from adult and fetal cells. Biol. Reprod. 62, 1135-1140.

Hill,K.G., Curry,J., DeMayo,F.J., Jones-Diller,K., Slapak,J.R., and Bondioli,K.R. (1992). Production of transgenic cattle by pronuclear injection. Theriogenology 37, 222. 
Ho,H.C. and Suarez,S.S. (2001). Hyperactivation of mammalian spermatozoa: function and regulation. Reproduction 122, 519-526.

Hodges,C.A. and Stice,S.L. (2003). Generation of bovine transgenics using somatic cell nuclear transfer. Reprod. Biol. Endocrinol. 1, 81.

Hofmann,A., Kessler,B., Ewerling,S., Kabermann,A., Brem,G., Wolf,E., and Pfeifer,A. (2006). Epigenetic regulation of lentiviral transgene vectors in a large animal model. Mol. Ther. 13, 59-66.

Hofmann,A., Kessler,B., Ewerling,S., Weppert,M., Vogg,B., Ludwig,H., Stojkovic,M., Boelhauve,M., Brem,G., Wolf,E., and Pfeifer,A. (2003). Efficient transgenesis in farm animals by lentiviral vectors. EMBO Rep. 4, 1054-1060.

Hofmann,A., Zakhartchenko,V., Weppert,M., Sebald,H., Wenigerkind,H., Brem,G., Wolf,E., and Pfeifer,A. (2004). Generation of transgenic cattle by lentiviral gene transfer into oocytes. Biol. Reprod. 71, 405-409.

Houdebine,L.M. (2000). Transgenic animal bioreactors. Transgenic Res. 9, 305-320. Houdebine, L. M. Animal transgenesis and cloning. 2003. John Wiley and Sons. Ref Type: Generic

Hunter,A.G. and Moor,R.M. (1987). Stage-dependent effects of inhibiting ribonucleic acids and protein synthesis on meiotic maturation of bovine oocytes in vitro. J. Dairy Sci. 70, 1646-1651.

Hunter,R.H. (1998). Have the Fallopian tubes a vital role in promoting fertility? Acta Obstet. Gynecol. Scand. 77, 475-486.

Hyttel,P., Fair,T., Callesen,H., and Greve,T. (1997). Oocyte growth, capacitation and final maturation in cattle. Theriogenology 47, 23-32.

Hyttel,P., Viuff,D., Fair,T., Laurincik,J., Thomsen,P.D., Callesen,H., Vos,P.L., Hendriksen,P.J., Dieleman,S.J., Schellander,K., Besenfelder,U., and Greve,T. (2001). Ribosomal RNA gene expression and chromosome aberrations in bovine oocytes and preimplantation embryos. Reproduction. 122 , 21-30. 
Hyttinen,J.M., Peura,T., Tolvanen,M., Aalto,J., Alhonen,L., Sinervirta,R., Halmekyto,M., Myohanen,S., and Janne,J. (1994). Generation of transgenic dairy cattle from transgene-analyzed and sexed embryos produced in vitro. Biotechnology (N. Y. ) 12, 606-608.

Iguma,L.T., Lisauskas,S.F., Melo,E.O., Franco,M.M., Pivato,I., Vianna,G.R., Sousa,R.V., Dode,M.A., Aragao,F.J., Rech,E.L., and Rumpf,R. (2005). Development of bovine embryos reconstructed by nuclear transfer of transfected and nontransfected adult fibroblast cells. Genet. Mol. Res. 4, 55-66.

Iwamoto,K., Ikeda,K., Yonezawa,N., Noguchi,S., Kudo,K., Hamano,S., Kuwayama,M., and Nakano,M. (1999). Disulfide formation in bovine zona pellucida glycoproteins during fertilization: evidence for the involvement of cystine crosslinkages in hardening of the zona pellucida. J. Reprod. Fertil. 117, 395-402.

Iwata,H., Hashimoto,S., Ohota,M., Kimura,K., Shibano,K., and Miyake,M. (2004). Effects of follicle size and electrolytes and glucose in maturation medium on nuclear maturation and developmental competence of bovine oocytes. Reproduction 127 , 159-164.

Jaenisch,R. (1976). Germ line integration and Mendelian transmission of the exogenous Moloney leukemia virus. Proc. Natl. Acad. Sci. U. S. A 73, 1260-1264.

Kay,M.A.; Glorioso,J.C.; Naldini,L. (2001). Viral vectors for gene therapy: the art of turning infectious agents into vehicles of therapeutics. Nature 7, $33-40$

Khurana,N.K. and Niemann,H. (2000). Effects of oocyte quality, oxygen tension, embryo density, cumulus cells and energy substrates on cleavage and morula/blastocyst formation of bovine embryos. Theriogenology 54, 741-756.

Kim,J.Y., Kinoshita,M., Ohnishi,M., and Fukui,Y. (2001). Lipid and fatty acid analysis of fresh and frozen-thawed immature and in vitro matured bovine oocytes.

Reproduction 122, 131-138.

Kochevar,I.E. (1989). Cytotoxicity and mutagenicity of excimer laser radiation. Lasers Surg. Med. 9, 440-445. 
Krimpenfort,P., Rademakers,A., Eyestone,W., van der,S.A., van den,B.S., Kooiman,P., Kootwijk,E., Platenburg,G., Pieper,F., Strijker,R., and . (1991).

Generation of transgenic dairy cattle using 'in vitro' embryo production. Biotechnology (N. Y. ) 9, 844-847.

Kuroiwa,Y., Kasinathan,P., Matsushita,H., Sathiyaselan,J., Sullivan,E.J., Kakitani,M., Tomizuka,K., Ishida,I., and Robl,J.M. (2004). Sequential targeting of the genes encoding immunoglobulin-mu and prion protein in cattle. Nat. Genet. 36, 775-780.

Lechniak,D., Kaczmarek,D., Stanislawski,D., and Adamowicz,T. (2002). The ploidy of in vitro matured bovine oocytes is related to the diameter. Theriogenology $57,1303-$ 1308.

Lewis,I.M. (1994). Splitting cattle embryos commercially: The effects of sucrose, embryo stage and the duration between embryo recovery and bisection.

Theriogenology 41, 237.

Lois,C., Hong,E.J., Pease,S., Brown,E.J., and Baltimore,D. (2002). Germline transmission and tissue-specific expression of transgenes delivered by lentiviral vectors. Science 295, 868-872.

Lorton,S.P. and First,N.L. (1979). Hyaluronidase does not disperse the cumulus oophorus surrounding bovine ova. Biol. Reprod. 21, 301-308.

Loveland,B.E., Milland,J., Kyriakou,P., Thorley,B.R., Christiansen,D., Lanteri,M.B., Regensburg,M., Duffield,M., French,A.J., Williams,L., Baker,L., Brandon,M.R., Xing,P.X., Kahn,D., and McKenzie,I.F. (2004). Characterization of a CD46 transgenic pig and protection of transgenic kidneys against hyperacute rejection in nonimmunosuppressed baboons 217. Xenotransplantation. 11, 171-183.

Lu,K.H., Gordon,I., Chen,H.B., Gallagher,M., and McGovern,H. (1988). Birth of twins after transfer of cattle embryos produced by in vitro techniques. Vet. Rec. 122, 539540.

Maga,E.A. (2005). Genetically engineered livestock: closer than we think? Trends Biotechnol. 23, 533-535. 
Mahmoud,A.I. and Parrish,J.J. (1996). Oviduct fluid and heparin induce similar surface changes in bovine sperm during capacitation: a flow cytometric study using lectins. Mol. Reprod. Dev. 43, 554-560.

McCreath,K.J., Howcroft,J., Campbell,K.H., Colman,A., Schnieke,A.E., and Kind,A.J. (2000). Production of gene-targeted sheep by nuclear transfer from cultured somatic cells. Nature 405, 1066-1069.

McGrew,M.J., Sherman,A., Ellard,F.M., Lillico,S.G., Gilhooley,H.J., Kingsman,A.J., Mitrophanous,K.A., and Sang,H. (2004). Efficient production of germline transgenic chickens using lentiviral vectors. EMBO Rep. 5, 728-733.

Melo,E.O., Sousa,R.V., Iguma,L.T., Franco,M.M., Rech,E.L., and Rumpf,R. (2005). Isolation of transfected fibroblast clones for use in nuclear transfer and transgene detection in cattle embryos. Genet. Mol. Res. 4, 812-821.

Miller,D.G., Adam,M.A., and Miller,A.D. (1990). Gene transfer by retrovirus vectors occurs only in cells that are actively replicating at the time of infection. Mol. Cell Biol. $10,4239-4242$.

Miyoshi,H., Blomer,U., Takahashi,M., Gage,F.H., and Verma,I.M. (1998).

Development of a self-inactivating lentivirus vector. J. Virol. 72, 8150-8157.

Muller,M. and Brem,G. (1998). Transgenic approaches to the increase of disease resistance in farm animals. Rev. Sci. Tech. 17, 365-378.

Nakagawa,T., Feliu-Mojer,M.I., Wulf,P., Lois,C., Sheng,M., and Hoogenraad,C.C. (2005). Generation of lentiviral transgenic rats expressing Glutamate Receptor Interacting Protein 1 (GRIP1) in brain, spinal cord and testis. J. Neurosci. Methods.

Naldini,L., Blomer,U., Gallay,P., Ory,D., Mulligan,R., Gage,F.H., Verma,I.M., and Trono,D. (1996a). In vivo gene delivery and stable transduction of nondividing cells by a lentiviral vector. Science $272,263-267$.

Naldini,L., Blomer,U., Gallay,P., Ory,D., Mulligan,R., Gage,F.H., Verma,I.M., and Trono,D. (1996b). In vivo gene delivery and stable transduction of nondividing cells by a lentiviral vector 90. Science 272, 263-267. 
Neer,J., Tadir,Y., Ho,P., Berns,M.W., Asch,R.H., and Ord,T. (1992). Microscopedelivered ultraviolet laser zona dissection: principles and practices. J. Assist. Reprod. Genet. 9, 513-523.

Niemann,H., Halter,R., Carnwath,J.W., Herrmann,D., Lemme,E., and Paul,D. (1999). Expression of human blood clotting factor VIII in the mammary gland of transgenic sheep. Transgenic Res. 8, 237-247.

Obruca,A., Strohmer,H., Blaschitz,A., Schonickle,E., Dohr,G., and Feichtinger,W. (1997). Ultrastructural observations in human oocytes and preimplantation embryos after zona opening using an erbium-yttrium-aluminium-garnet (Er:YAG) laser. Hum. Reprod. 12, 2242-2245.

Oyamada,T. and Fukui,Y. (2004). Oxygen tension and medium supplements for in vitro maturation of bovine oocytes cultured individually in a chemically defined medium. J. Reprod. Dev. 50, 107-117.

Palanker,D., Ohad,S., Lewis,A., Simon,A., Shenkar,J., Penchas,S., and Laufer,N. (1991). Technique for cellular microsurgery using the 193-nm excimer laser. Lasers Surg. Med. 11, 580-586.

Palmiter,R.D., Brinster,R.L., Hammer,R.E., Trumbauer,M.E., Rosenfeld,M.G., Birnberg,N.C., and Evans,R.M. (1992). Dramatic growth of mice that develop from eggs microinjected with metallothionein-growth hormone fusion genes. 1982.

Biotechnology 24, 429-433.

Park,C.K., Ohgoda,O., and Niwa,K. (1989). Penetration of bovine follicular oocytes by frozen-thawed spermatozoa in the presence of caffeine and heparin. J. Reprod. Fertil. 86, 577-582.

Parrish,J.J., Susko-Parrish,J.L., Leibfried-Rutledge,M.L., Critser,E.S., Eyestone,W.H., and First,N.L. (1986). Bovine in vitro fertilization with frozen-thawed semen. Theriogenology 25, 591-600.

Petters,R.M. (1994). Transgenic livestock as genetic models of human disease. Reprod. Fertil. Dev. 6, 643-645.

Pfeifer,A. (2004). Lentiviral transgenesis. Transgenic Res. 13, 513-522. 
Pfeifer,A., Ikawa,M., Dayn,Y., and Verma,I.M. (2002). Transgenesis by lentiviral vectors: lack of gene silencing in mammalian embryonic stem cells and preimplantation embryos. Proc. Natl. Acad. Sci. U. S. A 99, 2140-2145..

Piedrahita,J.A. (2000). Gene targeting in domestic species: a new beginning. Transgenic Res. 9, 261-262.

Piedrahita,J.A., Dunne,P., Lee,C.K., Moore,K., Rucker,E., and Vazquez,J.C. (1999). Use of embryonic and somatic cells for production of transgenic domestic animals. Cloning 1, 73-87.

Pinyopummintr,T. and Bavister,B.D. (1991). In vitro-matured/in vitro-fertilized bovine oocytes can develop into morulae/blastocysts in chemically defined, protein-free culture media. Biol. Reprod. 45, 736-742.

Pursel,V.G., Pinkert,C.A., Miller,K.F., Bolt,D.J., Campbell,R.G., Palmiter,R.D., Brinster,R.L., and Hammer,R.E. (1989). Genetic engineering of livestock. Science 244, 1281-1288.

Rainard,P. (2005). Tackling mastitis in dairy cows. Nat. Biotechnol. 23, 430-432.

Rehman,N., Collins,A.R., Suh,T.K., and Wright,J. (1994). Effect of sperm exposure time on in vitro fertilization and embryo development of bovine oocytes matured in vitro. Theriogenology 41, 1447-1452.

Renard,J.P., Zhou,Q., LeBourhis,D., Chavatte-Palmer,P., Hue,I., Heyman,Y., and Vignon,X. (2002). Nuclear transfer technologies: between successes and doubts. Theriogenology 57, 203-222.

Rink,K., Delacretaz,G., Salathe,R.P., Senn,A., Nocera,D., Germond,M., De Grandi,P., and Fakan,S. (1996). Non-contact microdrilling of mouse zona pellucida with an objective-delivered 1.48-microns diode laser. Lasers Surg. Med. 18, 52-62.

Robl,J.M., Kasinathan,P., Sullivan,E., Kuroiwa,Y., Tomizuka,K., and Ishida,I. (2003). Artificial chromosome vectors and expression of complex proteins in transgenic animals. Theriogenology 59, 107-113.

Rosochacki,S.J., Kozikova,L.V., Korwin-Kossakowski,M., Matejczyk,M., Poloszynowicz,J., and Duszewska,A.M. (2003). Noninvasive fluorescent screening of 
microinjected bovine embryos to predict transgene integration. Folia Biol. (Krakow. ) 51, 97-104.

Rubinson,D.A., Dillon,C.P., Kwiatkowski,A.V., Sievers,C., Yang,L., Kopinja,J., Rooney,D.L., Ihrig,M.M., McManus,M.T., Gertler,F.B., Scott,M.L., and Van Parijs,L. (2003). A lentivirus-based system to functionally silence genes in primary mammalian cells, stem cells and transgenic mice by RNA interference. Nat. Genet. 33, 401-406.

Schernthaner,W., Schmoll,F., Brem,G., and Schellander,K. (1997). Storing bovine ovaries for 24 hours between 15 and 21 [deg]C does not influence in vitro production of blastocysts. Theriogenology 47, 297.

Schmoll,F., Schneider,H., Montag,M., Wimmers,K., Rink,K., and Schellander,K. (2003). Effects of different laser-drilled openings in the zona pellucida on hatching of in vitro-produced cattle blastocysts. Fertil. Steril. 80 Suppl 2, 714-719.

Schnieke,A.E., Kind,A.J., Ritchie,W.A., Mycock,K., Scott,A.R., Ritchie,M., Wilmut,I., Colman,A., and Campbell,K.H. (1997). Human factor IX transgenic sheep produced by transfer of nuclei from transfected fetal fibroblasts. Science $278,2130-2133$.

Schroder,A.R., Shinn,P., Chen,H., Berry,C., Ecker,J.R., and Bushman,F. (2002). HIV-1 integration in the human genome favors active genes and local hotspots. Cell 110, 521-529.

Scott,B.B. and Lois,C. (2005). Generation of tissue-specific transgenic birds with lentiviral vectors. Proc. Natl. Acad. Sci. U. S. A 102, 16443-16447.

Seamark,R.F. (1994). Progress and emerging problems in livestock transgenesis: a summary perspective. Reprod. Fertil. Dev. 6, 653-657.

Seif,M., Edi-Osagie,E., Farquhar,C., Hooper,L., Blake,D., McGinlay,P., and Seif,M. (2005). Assisted hatching on assisted conception (IVF \& ICSI). Cochrane. Database. Syst. Rev. CD001894.

Shi,W., Zakhartchenko,V., and Wolf,E. (2003). Epigenetic reprogramming in mammalian nuclear transfer. Differentiation 71, 91-113.

Tadir,Y., Wright,W.H., Vafa,O., Liaw,L.H., Asch,R., and Berns,M.W. (1991). Micromanipulation of gametes using laser microbeams. Hum. Reprod. 6, 1011-1016. 
Tamassia,M., Nuttinck,F., May-Panloup,P., Reynier,P., Heyman,Y., Charpigny,G., Stojkovic,M., Hiendleder,S., Renard,J.P., and Chastant-Maillard,S. (2004). In vitro embryo production efficiency in cattle and its association with oocyte adenosine triphosphate content, quantity of mitochondrial DNA, and mitochondrial DNA haplogroup. Biol. Reprod. 71, 697-704.

Tanghe,S., Van Soom,A., Mehrzad,J., Maes,D., Duchateau,L., and de Kruif,A. (2003). Cumulus contributions during bovine fertilization in vitro. Theriogenology 60 , 135-149.

Thomassen,E.A., van Veen,H.A., van Berkel,P.H., Nuijens,J.H., and Abrahams,J.P. (2005). The protein structure of recombinant human lactoferrin produced in the milk of transgenic cows closely matches the structure of human milk-derived lactoferrin. Transgenic Res. 14, 397-405.

Tinney,G.M.; Windt,M.L.; Kruger,T.F.; Lombard,C.J. (2005). Use of a zona laser treatment system in assisted hatching: optimal laser utilization parameters. Fertil. Steril. 84, 1737 - 1741

Tiscornia,G., Singer,O., Ikawa,M., and Verma,I.M. (2003). A general method for gene knockdown in mice by using lentiviral vectors expressing small interfering RNA. Proc. Natl. Acad. Sci. U. S. A 100, 1844-1848.

Tomek,W., Melo Sterza,F.A., Kubelka,M., Wollenhaupt,K., Torner,H., Anger,M., and Kanitz,W. (2002). Regulation of translation during in vitro maturation of bovine oocytes: the role of MAP kinase, elF4E (cap binding protein) phosphorylation, and elF4E-BP1. Biol. Reprod. 66, 1274-1282.

Tuschl,T. and Borkhardt,A. (2002). Small interfering RNAs: a revolutionary tool for the analysis of gene function and gene therapy. Mol. Interv. 2, 158-167.

Verma,I.M. and Weitzman,M.D. (2005). Gene therapy: twenty-first century medicine. Annu. Rev. Biochem. 74, 711-738.

Wall,R.J. and Hawk,H.W. (1988). Development of centrifuged cow zygotes cultured in rabbit oviducts. J. Reprod. Fertil. 82, 673-680. 
Wall,R.J., Hawk,H.W., and Nel,N. (1992). Making transgenic livestock: genetic engineering on a large scale. J. Cell Biochem. 49 , 113-120.

Wall,R.J., Kerr,D.E., and Bondioli,K.R. (1997). Transgenic dairy cattle: genetic engineering on a large scale. J. Dairy Sci. 80 , 2213-2224.

Wall,R.J., Powell,A.M., Paape,M.J., Kerr,D.E., Bannerman,D.D., Pursel,V.G., Wells,K.D., Talbot,N., and Hawk,H.W. (2005). Genetically enhanced cows resist intramammary Staphylococcus aureus infection. Nat. Biotechnol. 23, 445-451.

Wall,R.J., Pursel,V.G., Hammer,R.E., and Brinster,R.L. (1985). Development of porcine ova that were centrifuged to permit visualization of pronuclei and nuclei. Biol. Reprod. 32, 645-651.

Wells,K.D. and Powell,A.M. (2000). Blastomeres from somatic cell nuclear transfer embryos are not allocated randomly in chimeric blastocysts. Cloning 2, 9-22.

Whitelaw,C.B., Radcliffe,P.A., Ritchie,W.A., Carlisle,A., Ellard,F.M., Pena,R.N., Rowe,J., Clark,A.J., King,T.J., and Mitrophanous,K.A. (2004). Efficient generation of transgenic pigs using equine infectious anaemia virus (EIAV) derived vector. FEBS Lett. $571,233-236$.

Wilmut,I., Schnieke,A.E., McWhir,J., Kind,A.J., and Campbell,K.H. (1997). Viable offspring derived from fetal and adult mammalian cells. Nature $385,810-813$.

Wolf,E., Arnold,G.J., Bauersachs,S., Beier,H.M., Blum,H., Einspanier,R., Frohlich,T., Herrler,A., Hiendleder,S., Kolle,S., Prelle,K., Reichenbach,H.D., Stojkovic,M., Wenigerkind,H., and Sinowatz,F. (2003). Embryo-maternal communication in bovine - strategies for deciphering a complex cross-talk. Reprod. Domest. Anim 38, 276289.

Wolf,E., Schernthaner,W., Zakhartchenko,V., Prelle,K., Stojkovic,M., and Brem,G. (2000). Transgenic technology in farm animals--progress and perspectives. Exp. Physiol 85, 615-625.

Zakhartchenko,V., Mueller,S., Alberio,R., Schernthaner,W., Stojkovic,M., Wenigerkind,H., Wanke,R., Lassnig,C., Mueller,M., Wolf,E., and Brem,G. (2001). 
Nuclear transfer in cattle with non-transfected and transfected fetal or cloned transgenic fetal and postnatal fibroblasts. Mol. Reprod. Dev. 60, 362-369.

Zakhartchenko,V., Wolf,E., Palma,G.A., and Brem,G. (1995). Effect of donor embryo cell number and cell size on the efficiency of bovine embryo cloning. Mol. Reprod. Dev. 42, 53-57.

Zennou,V., Petit,C., Guetard,D., Nerhbass,U., Montagnier,L., and Charneau,P. (2000). HIV-1 genome nuclear import is mediated by a central DNA flap. Cell 101, 173-185.

Zhang,L., Jiang,S., Wozniak,P.J., Yang,X., and Godke,R.A. (1995). Cumulus cell function during bovine oocyte maturation, fertilization, and embryo development in vitro. Mol. Reprod. Dev. 40, 338-344.

Zinovieva,N., Lassnig,C., Schams,D., Besenfelder,U., Wolf,E., Muller,S., Frenyo,L., Seregi,J., Muller,M., and Brem,G. (1998). Stable production of human insulin-like growth factor 1 (IGF-1) in the milk of hemi- and homozygous transgenic rabbits over several generations. Transgenic Res. 7, 437-447.

http://www.ornl.gov/sci/techresources/Human Genome/glossary/glossary g.shtml http:// www.sivb.org/edu terminology.asp http://www.biotech.wisc.edu/ServicesResearch/TransgenicAnimal/TransgenicMiceor Rats.asp http://cancer.ucsd.edu/Research/Shared/tgm/pronuclear.asp http://www.cardiogenesis.com/glossary.cfm 


\section{Acknowledgement}

I would like to thank Prof. Dr. E. Wolf for giving me the opportunity to do this dissertation and to work and learn at his institute. I am grateful for his immense support, in particular for numerous discussions and comments and for lots of time he spent in teaching me and helping me with all the required features of this doctorate.

I wish to thank Klaus Rink and Richard Hampl-Portenlänger (MTG) for providing the OCTAX ${ }^{\mathrm{TM}}$-Laser System and their courteguos technical support.

I wish to thank Myriam Weppert for generously sharing her profound knowledge in bovine IVP and statistical analysis.

Further, I want to thank Barbara Keßler for her patience in teaching me everything about pigs, for her moral support and physical help whenever needed.

Regina Klose I want to thank for introducing me in how to write abstracts and preserving me from dying by feeding me with zucchini and providing an opportunity to talk whenever needed.

My gratitude also goes to Sissy Stärk for often being at the right place at the right time.

All the other people from the Institute of Molecular Animal Breeding and Biotechnology I want to thank for creating a relaxed and familial atmosphere, which never felt as being at work.

My most special thank I wish to express to Walter. He knows why. 
Curriculum vitae

Name

Date of Birth

Place of Birth

Family status
Sonja Maria Ewerling

19.06.1974

Pfaffenhofen / IIm, Germany

single

\section{Education}

\begin{tabular}{|c|c|}
\hline 09/1980 - 07/1984 & Primary school Schweitenkirchen / Paunzhausen \\
\hline 09/1984 - 07/1993 & Grammar school "Schyren-Gymnasium Pfaffenhofen / IIm" \\
\hline 09/1993 - 10/1994 & Apprendiceship as Veterinary Assistance \\
\hline $11 / 1994-04 / 2000$ & $\begin{array}{l}\text { Studies of Veterinary Medicine, } \\
\text { Ludwig-Maximilian-University Munich, } \\
\text { State examination }\end{array}$ \\
\hline $05 / 2000-03 / 2002$ & $\begin{array}{l}\text { substitutional direction of the Public Relation department } \\
\text { of Gold-Star TV }\end{array}$ \\
\hline since $04 / 2002$ & $\begin{array}{l}\text { Department for Molecular Animal Breeding and } \\
\text { Biotechnology, Ludwig-Maximilian-University Munich, } \\
\text { Chair: Prof. Dr. E. Wolf }\end{array}$ \\
\hline nce $05 / 2005$ & $\begin{array}{l}\text { Dissertation: "Laser-Assisted Lentiviral Transgenesis in } \\
\text { Bovine" }\end{array}$ \\
\hline
\end{tabular}

